\title{
Development of one-part alkali activated ceramic/slag binders containing recycled ceramic aggregates
}

\author{
Abdollahnejad Z. ${ }^{1 *}$, Luukkonen T. ${ }^{2}$, Mastali M. ${ }^{3}$, Kinnunen P. ${ }^{4}$, Illikainen M. ${ }^{5}$ \\ 1. Fibre and Particle Engineering, Faculty of Technology, Univ. of Oulu, P.O. Box 4300, 90014 \\ Oulu, Finland *Corresponding author Email: Zahra.abdollahnejad@oulu.fi \\ 2. Fibre and Particle Engineering, Faculty of Technology, Univ. of Oulu, P.O. Box 4300, 90014 \\ Oulu, Finland. Email: tero.luukkonen@oulu.fi \\ 3. Fibre and Particle Engineering, Faculty of Technology, Univ. of Oulu, P.O. Box 4300, 90014 \\ Oulu, Finland. Email: mohammad.mastali@oulu.fi \\ 4. Fibre and Particle Engineering, Faculty of Technology, Univ. of Oulu, P.O. Box 4300, 90014 \\ Oulu, Finland. Email: paivo.Kinnunen@oulu.fi \\ 5. Fibre and Particle Engineering, Faculty of Technology, Univ. of Oulu, P.O. Box 4300, 90014 \\ Oulu, Finland. Email: mirja.illikainen@oulu.fi
}

\begin{abstract}
Alkali-activated binders have received a great attention due to their excellent potential in enabling the reuse and recycling of industrial solid wastes and by-products. One-part or "just add water" alkali-activated binders are an approach to reduce the negative aspects of using alkali solution during the preparation of the traditional two-part alkali activated binders. The work aimed to utilize the maximum content of ceramic wastes in alkali-activated blast-furnace slag/ceramic binders. The ground granulated blast-furnace slag was partially replaced (10\%, 20\%, and 30\% in wt.\%) by two types of ceramic wastes (porcelain and raw; i.e., fired and unfired). Moreover, coarse particle size of porcelain ceramic waste was used as recycled aggregate. The specimens were cured under two different curing regimes: 1) sealing with plastic; 2) using thermal curing conditions for 3 hours in $60^{\circ} \mathrm{C}$ after demolding and then sealing until the test day. Mechanical testing and microstructural analysis were used to characterize the effects of different curing regimes and different ceramic sources. The results showed that replacing ground granulated blast furnace slag with all types of ceramic wastes reduced the compressive strength, which this reduction was mainly caused by reduction of the calcium content. This strength loss was also governed by the ceramic waste type, curing regime type, and curing duration. The microstructural analysis indicated that some cracks were formed between the ceramic waste particles and the matrix. Moreover, the microscopic analysis indicated the use of pre-heating could eliminate cracking.
\end{abstract}

Keywords: One-part alkali activated binders, Ceramic waste, Ground granulated blast furnace slag, Recycled ceramic aggregate, Compressive strength, Microstructural analysis 


\section{Introduction}

Manufacturing of ordinary Portland cement (OPC) consumes a high amount of natural resources (such as limestone and clay) and requires high temperature $\left(1450-1550^{\circ} \mathrm{C}\right.$ ), which results in releasing a high amount of greenhouse gases to the atmosphere (around 1 ton of $\mathrm{CO}_{2}$ per ton of cement production) (García-Lodeiro et al. 2011).

The OPC production process is one of the main causes of the global warming process, causing approximately 7-8\% of global warming $\mathrm{CO}_{2}$ emissions (García-Lodeiro et al. 2015; Andrew 2018). According to the various drawbacks caused by the production and utilization of a high amount of OPC, some alternative binders with lower $\mathrm{CO}_{2}$ emissions, such as calcium sulphoaluminate, alkali-activated materials, and hybrid alkaline cements, have been proposed (Shi et al. 2011).

Alkali activation of industrial wastes can reduce the exploitation of non-renewable raw materials, pollution, energy consumption, and the area used for waste landfills, all of which can mitigate global warming (Behera et al. 2014). Various wastes, such as crushed OPC concrete and bricks, could be used as recycled aggregates (Bernal et al. 2010). The quality, quantity, size, and type of recycled aggregate need to be precisely characterized, as these parameters strongly affect the mechanical properties and durability of the designed concrete (Reig et al. 2017).

In general, using recycled aggregate leads to degrade mechanical characteristics, which is due to the irregular particle shape and size distribution of recycled aggregates, and thus complicates vibrating and filling the gaps between particles (Eckert and Oliveira 2017; Shaikh 2016).

Ceramic materials represent about $45 \%$ of construction and demolition waste, which is produced during the demolition process, but rejected tiles, bricks, and other items from industry also result in ceramic wastes (Reig et al. 2013). Although these materials are mainly used as a road subbase or construction backfill materials, they can be employed as supplementary cementitious materials or even as raw materials for alkali-activated binders (Puertas et al. 2008; Lavat et al. 2009; Nuran and Mevlut 2000; Pereira-de-Oliveira et al. 2012).

A large quantity of waste is formed in the production stage, it has been reported about $30 \%$ of the daily manufacturing volume in the ceramic industry goes to waste (Senthamarai and Devadas Manoharan 2005). In Europe, the amount of waste in the different production stages of the ceramic industry reaches $3-7 \%$ of its global production (Fernandes et al. 2004). Moreover, regarding the data from the Spanish National Institute of Statistics (INE 2013) and the construction sector in Spain produced 32.7 Mt tons of waste in 2011, which 54\% was ceramics (GdE 2011). Therefore, the usage of this amount of recycled materials as binder, activator, and aggregates could bring cost efficiency and environmental benefits (Mas et al. 2015). Thus, various efforts 
have been made to investigate the effects of using ceramic wastes as a natural aggregate replacement (sand or gravel) (Sánchez De Rojas et al. 2007; Silva et al. 2008; Frías et al. 2008; Sánchez De Rojas et al. 2001; Sánchez De Rojas et al. 2006).

Ceramic wastes were classified by type and production process by Pacheco-Torgal and Jalali (2010). Regarding the proposed categories, there are two groups in accordance with the source of raw materials, including white and red pastes (Pacheco-Torgal and Jalali 2010). Concerning this classification, all ceramic wastes are fired. The only differences are governed by the firing time (once or twice). The fired wastes generated with the structural ceramic factories use only red pastes to manufacture their products such as brick, blocks, and roof tiles. The second fired ceramic waste produced in stoneware ceramic such as wall, floor tiles, and sanitary ware (Pacheco-Torgal and Jalali 2010).

Poon and Chan investigated the effects of using brick and ceramic waste (with particle size distribution of $5 \mathrm{~mm}$ or less) as a partial replacement for up to $20 \%$ of natural sand on fresh and hardened properties of concrete (Poon and Chan 2007). This replacement caused some strength reduction, however, this decrease could be minimized by using a double mixing method (Poon and Chan 2007). In the double mixing method, the coarse and fine aggregate are initially mixed for 1 minute. Half of the required water is added and mixed with the aggregate for one additional minute. After that, binder is added and mixed with the aggregate for approximately 1 minute. Finally, the rest of the required water is added, and the materials are mixed further for 90 seconds before casting.

Waste ceramic is a silicon-rich material that can be used as a precursor in the preparation of geopolymers (Toniolo and Boccaccini 2017; Vickers et al. 2015). Therefore, the use of ceramic waste and calcined clay as optional cementitious materials have received interests in the cement industry (Wild et al. 1997; Turanli et al. 2003; Toledo Filho et al. 2007; Gonçalves et al. 2009). Sanches De Rojas et al. (2007) and Goncalves et al. (2009) showed that replacing cement with calcined clay increased the total porosity and decreased the compressive strength.

Puertas et al. (2008) successfully used up to $35 \%$ of ceramic waste as pozzolanic admixtures (with particle size distribution of $d_{90} \leq 0.56 \mathrm{~mm}$ ), which proved the compatibility of using these raw materials in the production of cement clinker. Moreover, Shafiq et al. (2017) reported promising results for the acid resistance of alkali-activated slag binders incorporating ceramic waste as the precursors, when compared to OPC-based binders.

The effects of using tile ceramic wastes as a precursor and recycled aggregate were investigated by Reig et al. (2017). In their study, calcium hydroxide and ceramic waste powder were used as the dry ingredients, and it was mixed by an alkali-activated solution. Different aggregate types 
were used with a binder-to-aggregate weight ratio of 1:3 (ceramic, limestone sand, siliceous sand, crushed brick, and crushed sanitary ware) and particle size with a maximum diameter of 2 or 4 $\mathrm{mm}$. The compressive strength of the mix compositions was characterized under two different curing regimes, including an ambient temperature and thermal curing with temperature of $65^{\circ} \mathrm{C}$ for 3 days. Their results demonstrated that the aggregate type has a critical role in the strength gain with respect to the curing conditions (Reig et al. 2017).

According to the best of the author's knowledge, no extensive experimental study has been carried out on the effect of recycled ceramic waste is being used as a total replacement for normal sand and ceramic waste powder simultaneously is being employed as a precursor for mechanical properties of one-part alkali-activated slag binders. Also, no one has conducted an experimental study on the impacts of using ceramic wastes as a precursor in two different types (raw and porcelain) and as a partial replacement for slag and using ceramic waste (porcelain) as recycled fine aggregate in one-part alkali-activated slag binders. Furthermore, two different curing regimes (sealing and thermal curing) were used to cure the specimens, and their compressive strengths were evaluated at an early ( 7 days) and final (28 days) age. In this investigation, the differences in the raw and porcelain ceramics are derived from using glaze to cover surface of ceramics. This coating layer is a vitreous substance, which has been fused to a ceramic body through firing. It will be shown that both ceramic wastes have almost similar chemical components, the only difference will be detected in the calcium content.

\section{Experimental program}

\section{Materials and mix designs}

The designed alkali-activated binders are composed of ground granulated blast furnace slag (GGBFS), ceramic wastes (raw and porcelain; i.e., unfired and fired ceramic, respectively), water, and anhydrous sodium metasilicate $\left(\mathrm{Na}_{2} \mathrm{SiO}_{3}\right)$ with a silica modulus of $\mathrm{SiO}_{2} / \mathrm{Na}_{2} \mathrm{O}=0.9\left(\mathrm{~d}_{50}\right.$ value $\leq 20 \mu \mathrm{m})$.

Alkali-activated materials are involved concentrated aqueous alkali solutions, which are corrosive, viscous, and, as such, difficult to handle and not user friendly. Consequently, the development of so-called one-part or "just add water" alkali activated binders may have greater potential than the conventional two-part alkali activated binders (containing dangerous liquid), especially in cast-insitu applications (Luukkonen et al. 2018a). One-part alkali activated binders comprise of a dry mix that consist of a solid aluminosilicate precursor (such as fly ash, slag, metakaloin, soap stone, ceramics), a solid alkali source, and possible admixtures to which water is added, like the preparation procedure is used for OPC based compositions. 
The ceramic wastes (see Fig. 1) were provided by a Finnish sanitary ware manufacturer, IDO. The raw ceramic waste (unfired) can be reused in the sanitary ware manufacturing process, while the non-usable porcelain waste (fired) is produced at a rate of 1,200 t/year. The ground granulated blast-furnace slag was from Finnsementti (Finland), which supplies it as a supplementary cementitious material. The used slag had $a d_{50}$ value and density of $10.8 \mu \mathrm{m}$ and $2.93 \mathrm{~g} / \mathrm{cm}^{3}$, respectively.

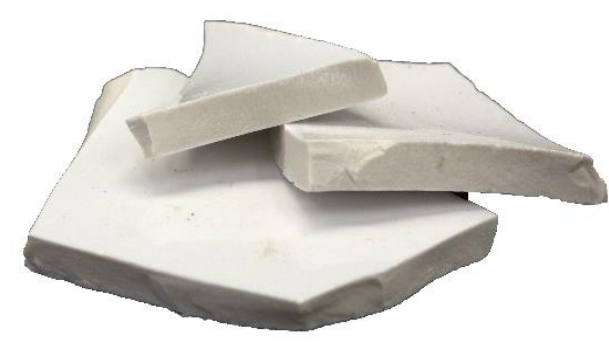

a)

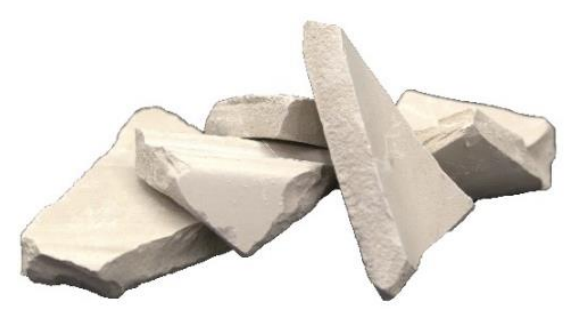

b)

Fig 1. a) Porcelain (fired) ceramic waste; b) raw (unfired) ceramic waste as received. The particles had maximum dimensions of approximately $50 \mathrm{~mm}$ before milling.

The chemical compositions of the ground granulated blast-furnace slag and two other different ceramic wastes were determined by using X-ray fluorescence (XRF). They are presented in Table 1. The chemical compositions were determined with a $4 \mathrm{kV}$ wavelength dispersive $X$-ray fluorescence (XRF) spectrometer (PANalytical AxiosmAX). XRF analyses were performed from fused samples: $1.5 \mathrm{~g}$ of sample was melted at $1150^{\circ} \mathrm{C}$ with $7.5 \mathrm{~g}$ of X-ray Flux Type 66:34 (66\% $\mathrm{Li}_{2} \mathrm{~B}_{4} \mathrm{O}_{7}$ and $34 \% \mathrm{LiBO}_{2}$ ) to obtain melt-fused tablets. 
Table 1. The chemical composition of slag and two different ceramic wastes (fired and unfired) as determined with XRF.

\begin{tabular}{|c|c|c|c|}
\hline Element / oxide, $(\%, \mathbf{w} / \mathbf{w})$ & GGBFS & Fired ceramic waste $^{*}$ & ${\text { Unfired ceramic } \text { waste }^{\star *}}^{\mathrm{Na}_{2} \mathrm{O}}$ \\
\hline $\mathrm{MgO}$ & 0.51 & 2.20 & 2.00 \\
\hline $\mathrm{Al}_{2} \mathrm{O}_{3}$ & 10.24 & 0.31 & 0.13 \\
\hline $\mathrm{SiO}_{2}$ & 9.58 & 21.01 & 20.96 \\
\hline $\mathrm{P}_{2} \mathrm{O}_{5}$ & 32.33 & 67.06 & 64.80 \\
\hline $\mathrm{SO}_{3}$ & 0.01 & 0.07 & 0.09 \\
\hline $\mathrm{K}_{2} \mathrm{O}$ & 4.00 & 0.02 & 0.02 \\
\hline $\mathrm{CaO}_{\mathrm{Cr}_{2} \mathrm{O}_{3}}$ & 0.53 & 2.32 & 2.25 \\
\hline $\mathrm{MnO}_{\mathrm{Fe}} \mathrm{O}_{3}$ & 38.51 & 1.45 & 0.30 \\
\hline & 0.00 & 0.04 & 0.01 \\
\hline & 0.00 & 0.02 & 0.00 \\
\hline
\end{tabular}

Fired ceramic waste*: Porcelain

Unfired ceramic waste ${ }^{\star \star}:$ Raw

The raw and porcelain ceramics were milled to obtain a grain size less than $0.5 \mathrm{~mm}$, while the porcelain ceramic waste as fine aggregate had a particle size distribution between $0.5 \mathrm{~mm}$ and 4 $\mathrm{mm}$ after milling.

These two types of ceramic wastes (porcelain and raw; i.e., fired and unfired) with a grain size less than $0.5 \mathrm{~mm}$ were used as a partial replacement (10\%, 20\%, and $30 \%$ in wt.\%) of ground granulated blast-furnace slag. Tap water was used to all mix compositions throughout the experimental program.

It is worth stating that the porcelain ceramic waste was used as fine aggregate in all mix compositions, while the use of raw ceramic waste as aggregate (with a particle size distribution between $0.5 \mathrm{~mm}$ and $4 \mathrm{~mm}$ after milling) significantly increased the amount of water (water absorption was measured 14\%), and this affected the strength developments. Therefore, only porcelain ceramic waste used as fine aggregate in all mix compositions (water absorption was recorded 10\%). This lower water absorption may be justified by the presence of the glaze layer, which covered the ceramic surface and the glaze layer does not allow to absorb more water.

Additionally, the water demand of recycled aggregates could be governed by the initial moisture states of recycled aggregates, which mainly depend on the type of the drying conditions. In the present paper, the recycled fine aggregates used as the air dried condition. 


\section{Specimen synthesis and ageing}

In the batching process, slag, ceramic wastes, and solid sodium silicate were initially mixed for 3 minutes. Then, water was added to the mixture, and then the mix composition was stirred for a further $3 \mathrm{~min}$. The cylindrical molds with a dimension of $20 \mathrm{~mm}$ (in height) $\times 20 \mathrm{~mm}$ (in diameter) were filled by fresh mortar and then the molds were vibrated for 30 seconds. Finally, the surfaces of specimens were flatted by using a spatula after vibration. The compressive strength was evaluated by using these cylinders.

After casting, the specimens were kept sealed in plastic bags and then, the sealed specimens were kept inside the lab conditions (at a temperature of $23^{\circ} \mathrm{C}$ and a relative humidity of $35 \%$ ) for 24 hours, and then the specimens were demolded and cured in two different regimes until the test day, including: 1) sealing with plastic bags, 2) using a thermal curing condition ( 3 hours at $60{ }^{\circ} \mathrm{C}$ ), and then sealing with plastic bags until the test day ( 7 and 28 days).

Several investigations have demonstrated the efficiency of using thermal approach for different alkali-activated binders in order to enhance the compressive strength (Kim and Kim 2013; Atis et al. 2015; Ming et al. 2016). Abdollahnejad et al. showed that using a thermal approach with the temperature of $60^{\circ} \mathrm{C}$ for three hours enhanced the strength of alkali activated cements, therefore, similar thermal methodology was adopted here in this study (Abdollahnejad et al. 2017). The early and final ages were examined by 7 and 28 days, respectively. The previous findings in (Akçaözoglu and Ulu 2014; Berna et al. 2012; Altan and Erdogan 2012; Aydın and Baradan 2013) indicated that the compressive strengths of alkali activated slag based binders developed rapidly at early ages up to 7 days, then the increase rate of compressive strength slowed down up to 28 days. Replacing slag with ceramic binders slows down the formation of the chemical reactions compared to the reference mix composition (based on the results shown later), therefore, the final strength was assessed after 28 days.

The mixture designations and mass proportions of the mix compositions are presented in Table 2. It is worth mentioning that the reference mix composition was selected based on earlier literature (Luukkonen et al. 2018b). The only difference was related to the usage of recycled ceramic aggregate in the present paper instead of the standard sand. 
Table 2. The mass proportions of mix compositions $\left(\mathrm{kg} / \mathrm{m}^{3}\right)$.

\begin{tabular}{|c|c|c|c|c|c|c|}
\hline Mixtures & GGBFS & $\begin{array}{c}\text { Unfired } \\
\text { ceramic } \\
\text { waste }\end{array}$ & $\begin{array}{c}\text { Fired } \\
\text { ceramic } \\
\text { waste }\end{array}$ & $\begin{array}{l}\text { Sodium } \\
\text { metasilicate }\end{array}$ & Water & $\begin{array}{c}\text { Porcelain ceramic as } \\
\text { aggregates } \\
\text { ( } 0.5 \mathrm{~mm} \leq \text { grain size } \leq \\
4 \mathrm{~mm} \text { ) }\end{array}$ \\
\hline Reference & 1171.90 & 0.00 & 0.00 & 130.20 & 455.70 & 2604.2 \\
\hline $10 \mathrm{~F}^{\star}$ & 1041.70 & 0.00 & 130.20 & 130.20 & 455.70 & 2604.2 \\
\hline $20 \mathrm{~F}$ & 911.50 & 0.00 & 260.40 & 130.20 & 455.70 & 2604.2 \\
\hline $30 \mathrm{~F}$ & 781.30 & 0.00 & 390.60 & 130.20 & 455.70 & 2604.2 \\
\hline $10 U^{\star *}$ & 1041.70 & 130.20 & 0.00 & 130.20 & 455.70 & 2604.2 \\
\hline $20 U$ & 911.50 & 260.40 & 0.00 & 130.20 & 455.70 & 2604.2 \\
\hline $30 \mathrm{U}$ & 781.30 & 390.60 & 0.00 & 130.20 & 455.70 & 2604.2 \\
\hline
\end{tabular}

$F^{\star}$ : Porcelain ceramic waste

$\mathrm{U}^{\star \star}$ : Raw ceramic waste

In total, regarding the mix compositions, 84 specimens were cast and tested to assess the compressive strength. It is worth stating that the mentioned mixture designations in Table 2 are assigned to the compositions, which were cured at the ambient conditions. The letter "T" was added to the mixture designations to show that thermal curing was imposed to the specimens.

The molar ratios of the proposed mix compositions assuming total solubility of raw materials were computed and presented in Table 3. Based on the molar ratios of the mix compositions, the main difference is in the $\mathrm{CaO} / \mathrm{SiO}_{2}$ molar ratios. This difference between mixtures mainly arises from the partial replacement of slag by ceramic wastes.

Table 3. Molar ratios of mixtures.

\begin{tabular}{|c|c|c|c|c|c|c|}
\hline \multirow{2}{*}{ Mixtures } & \multicolumn{6}{|c|}{ Molar ratios } \\
\hline & $\mathrm{SiO}_{2} / \mathrm{Al}_{2} \mathrm{O}_{3}$ & $\mathrm{Na}_{2} \mathrm{O} / \mathrm{SiO}_{2}$ & $\mathrm{Na}_{2} \mathrm{O} / \mathrm{Al}_{2} \mathrm{O}_{3}$ & $\mathrm{CaO} / \mathrm{SiO}_{2}$ & $\mathrm{H}_{2} \mathrm{O} / \mathrm{Na}_{2} \mathrm{O}$ & $\mathrm{H}_{2} \mathrm{O} / \mathrm{Al}_{2} \mathrm{O}_{3}$ \\
\hline Reference & 5.61 & 0.06 & 0.32 & 0.24 & 69.86 & 22.35 \\
\hline $10 \mathrm{~F}$ & 5.60 & 0.06 & 0.32 & 0.21 & 68.68 & 21.86 \\
\hline $20 \mathrm{~F}$ & 5.59 & 0.06 & 0.32 & 0.18 & 67.53 & 21.39 \\
\hline $30 \mathrm{~F}$ & 5.58 & 0.06 & 0.32 & 0.16 & 66.42 & 20.93 \\
\hline $10 \mathrm{U}$ & 5.59 & 0.06 & 0.32 & 0.21 & 68.81 & 21.86 \\
\hline $20 U$ & 5.57 & 0.06 & 0.32 & 0.18 & 67.80 & 21.39 \\
\hline $30 U$ & 5.56 & 0.06 & 0.31 & 0.16 & 66.81 & 20.94 \\
\hline
\end{tabular}




\section{Test procedures and setups}

\section{Compressive test}

The compressive strength of each composition was assessed as an average of the three cylindrical specimens with dimensions of $20 \mathrm{~mm}$ (in height) $\times 20 \mathrm{~mm}$ (in diameter). The ASTM $\mathrm{C} 109$ (2016) recommendation was used to obtain the compressive strength. All the cylinders were assessed by using a Zwick, Z100 Roell testing machine with a load cell of $100 \mathrm{kN}$ and a speed rate of $1.8 \mathrm{~mm} / \mathrm{min}$.

\section{Microstructural analysis}

After assessing the mechanical properties, the specimens were crushed to obtain the untested cores and use them in the microstructural analysis. This analysis was carried out 2-3 days after the mechanical testing, therefore, the effects of carbonation on the microstructure were ignored. The morphology and chemical compound identifications were executed by scanning electron microscope (SEM) images and X-Ray Diffraction (XRD) analysis, respectively.

To take SEM images, some small parts of the mixtures (mortars) were selected and their hydration processes were stopped by using solvent exchange (methanol/acetone mixture) and oven dry method (Lee et al. 2016; Chen et al. 2014). In this study, the SEM images were provided using a Zeiss Ultra Plus machine with an acceleration voltage of $15 \mathrm{kV}$ and a distance that varied in the range of $6 \mathrm{~mm}$ to $8 \mathrm{~mm}$. Energy-dispersive X-ray spectroscopy (EDX) was carried out to obtain the atomic ratio analysis using the average of four points in the SEM images from Figs 5 and 6. For execution of both XRD and TGA analysis, the pastes were milled using a Mortar Grinder RM 200 , which is suitable for the proper and reproducible sample preparation to analytical fineness. The pastes were milled in this machine for at least 10 minutes. Then, the powder was used for further investigations in XRD and TGA analysis. An XRD analysis was performed on different pastes to investigate the crystalline phase of the specimens and the effects of thermal curing on possible phase changes. The XRD data were collected by using X-ray diffraction (XRD) and a Rigaku Smartlab diffractometer ( $9 \mathrm{~kW}$ Cu X-ray source) in the range of $13-90{ }^{\circ} 2 \theta$ using a 6 ${ }^{\circ} 2 \theta /$ min scan speed.

Using the ICDD PDF4 database from the International Center for Diffraction Data, the phase identification was performed by comparing the different pattern to identify the phases. The phase identification was detected by Jade 7 software, version 5.1.2600, from Materials Data Inc.

To study the reaction products and the conversion processes, a thermogravimetric analysis (TGA) and differential thermogravimetry (DTG) were carried out on the 28-day paste samples using the 
Precisa Gravimetrics AG "prepASH automatic drying and ashing system" The samples were crushed and heated up to $1000^{\circ} \mathrm{C}$ at $10^{\circ} \mathrm{C} / \mathrm{min}$ in a nitrogen atmosphere.

\section{Results and discussion}

\section{Compressive strength}

The influences of replacing slag with ceramic wastes (porcelain and raw) on the compressive strength of the mixtures at an early age ( 7 days) are indicated in Figs 2 and 3 under two different curing regimes.

The effect of replacing ground granulated blast-furnace slag with porcelain ceramic waste by $10 \%$, $20 \%$, and $30 \%$ (in wt.\%) is shown in Fig. 2a. By increasing the amount of porcelain ceramic waste, a reduction can be observed in the compressive strength for both ambient and thermal curing conditions. This can be explained by the low reactivity of porcelain ceramic waste compared to slag or even the lack of chemical reactions between the activating solution and ceramic waste.

The maximum compressive strength was approximately $20 \mathrm{MPa}$ for the mix composition with $100 \%$ porcelain ceramic waste as fine aggregate (reference mix composition). The minimum compressive strength was around $10 \mathrm{MPa}$, which showed about a $50 \%$ reduction because of the replacement of slag by $30 \%$ porcelain ceramic waste.

The experimental results related to the effects of replacement of slag up to $30 \%$ by raw ceramic wastes on development of strength are shown in Fig. 2b. The results indicated that the effects of curing regime become more important with replacing slag with ceramic wastes at the early ages, so that a reduction around 7 times was recorded in mix composition containing $30 \%$ raw ceramic waste and cured at the ambient condition compared to specimens cured at thermal conditions.

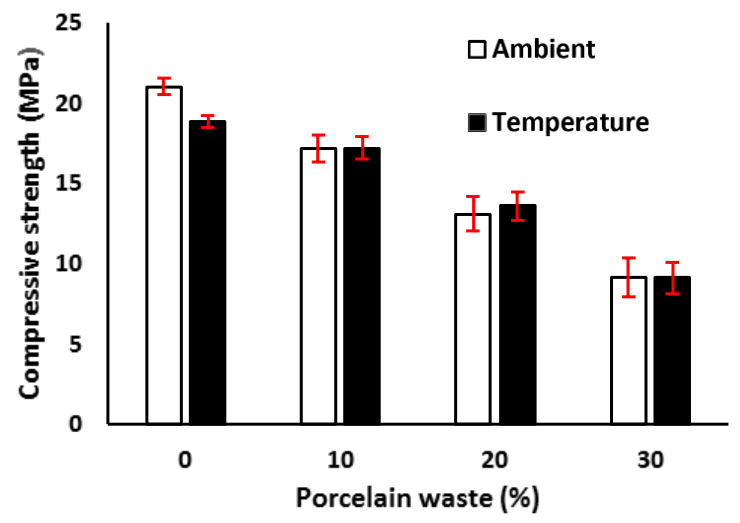

a)

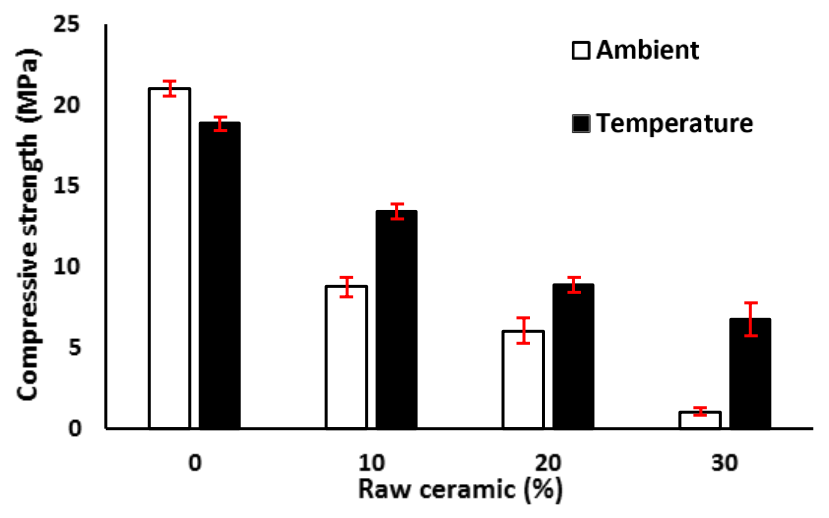

b)

Fig 2. Effect of replacement of slag by two different ceramic wastes on 7 days compressive strength: a) porcelain ceramic; b) raw ceramic. 
The strength of specimens at the final age (28 days) of the mix compositions are shown in Fig. 3. Regarding the results, slight improvement recorded due to the use of thermal curing at the final age. The maximum compressive strength after 28 days was approximately $25 \mathrm{MPa}$ for the reference mix composition cured at the ambient conditions, which showed a $25 \%$ increase in strength compared to the 7 day strength.

As depicted in Fig. 3a, slight improvements were observed in the strength of compositions due to thermal curing except the reference mix composition, which had around a $15 \%$ reduction. The maximum strength increase was recorded about $25 \%$ in the mix composition with $20 \%$ porcelain ceramic waste and cured at thermal condition. The reduction of the compressive strength after exposing to the temperature was justified by the damage caused by the formation of the cracks between the two thermally incompatible ingredients, paste and aggregate (Biolzi et al. 2008).

As shown in Fig. 3a, replacing slag with porcelain ceramic waste above $20 \%$ had no further harmful effects on the reduction of the compressive strength at the final age of specimens cured at the ambient conditions. The lowest compressive strength was related to the mix composition with $30 \%$ raw ceramic waste (around $12 \mathrm{MPa}$ ) and cured at ambient condition, which compared to the reference mix composition showing a $50 \%$ reduction, approximately.

The only difference could be derived from the values of compressive strength of the mix compositions at the early and final ages, which is caused by increasing the degree of polymerization.

Using thermal pre-curing accelerated the chemical reactions in the one-part alkali-activated ceramic/slag binders containing raw ceramic waste, and subsequently, this curing method enhanced the strength gain at the early age.

Additionally, it was noticed that thermal curing led to obtaining the maximum increase of the strength in the mix composition with $30 \%$ raw ceramic waste (about $20 \%$ ) at the final age, as depicted in Fig. 3b.

Comparing the effects of using thermal curing on the early and final age compressive strength revealed that heating had a high impact on enhancing the compressive strength of compositions containing raw ceramic waste precursor at the early age. Otherwise, thermal curing had no significant impact on the strength gain at the final age. Moreover, significant variations were not observed in the compositions containing porcelain ceramic wastes at the early and final ages.

Unlike the compressive strength obtained for the mix compositions containing porcelain ceramic wastes, increasing curing time had a significant impact on increasing the compressive strength of mix compositions using raw ceramic waste and cured at the ambient conditions, as shown in Figs 
$2 \mathrm{~b}$ and $3 \mathrm{~b}$. Meanwhile, an abrupt strength loss was detected due to replacing slag with raw ceramic waste at the early age of specimens cured at the ambient conditions. Due to the increase of curing time from 7 to 28 days, the degree of polymerization increased and the maximum increase of compressive strength achieved about a 10-fold level in the composition containing $30 \%$ ceramic waste. In general, it could be concluded that the ambient conditions had a greater effect than thermal curing conditions on increasing the strength in the mix compositions containing raw ceramic wastes.

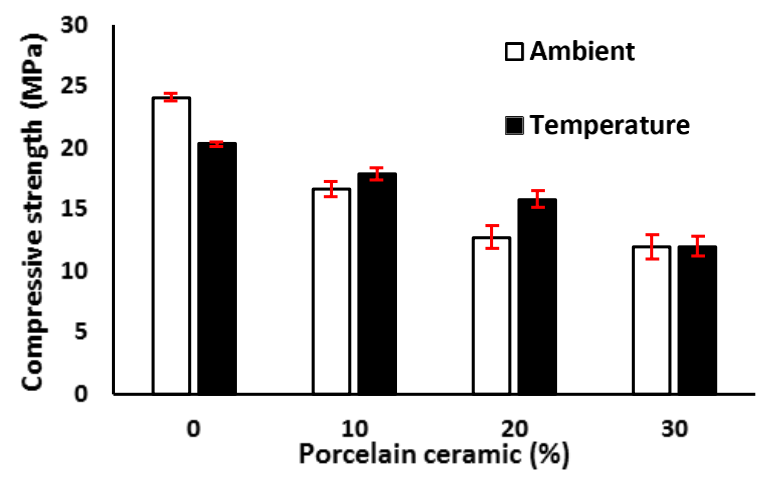

a)

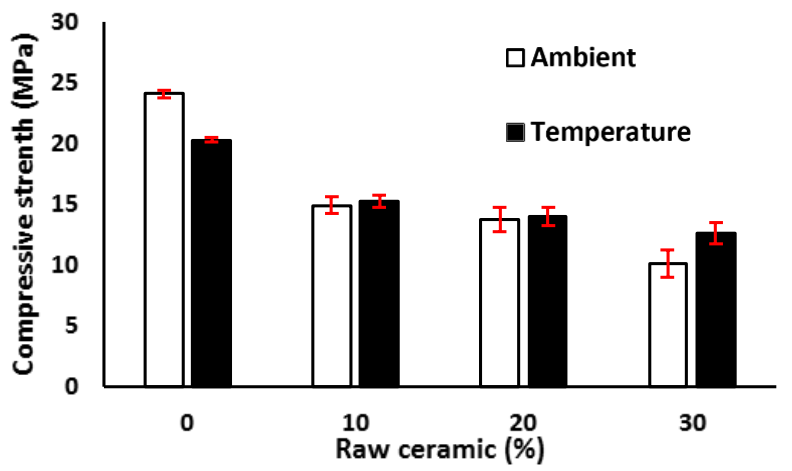

b)

Fig 3. Effect of replacement of slag by two different ceramic wastes at 28 days of compressive strength: a) porcelain ceramic; b) raw ceramic.

Fig. 4 shows the correlation between the compressive strength and the ceramic waste content used as a precursor, derived using linear regression analysis. As illustrated in Fig. 4a, a linear relationship between the compressive strength and the ceramic waste content is found at the early age, with a high coefficient of determination $\left(R^{2} \geq 0.9\right)$. Obtaining $R^{2}$ equal to 0.7 or higher is sufficient for developing a reasonably reliable linear model (Rahmani et al. 2012). Therefore, regarding the developed equations, it could be concluded that equations have good reliability for the imposed conditions in the present paper. 


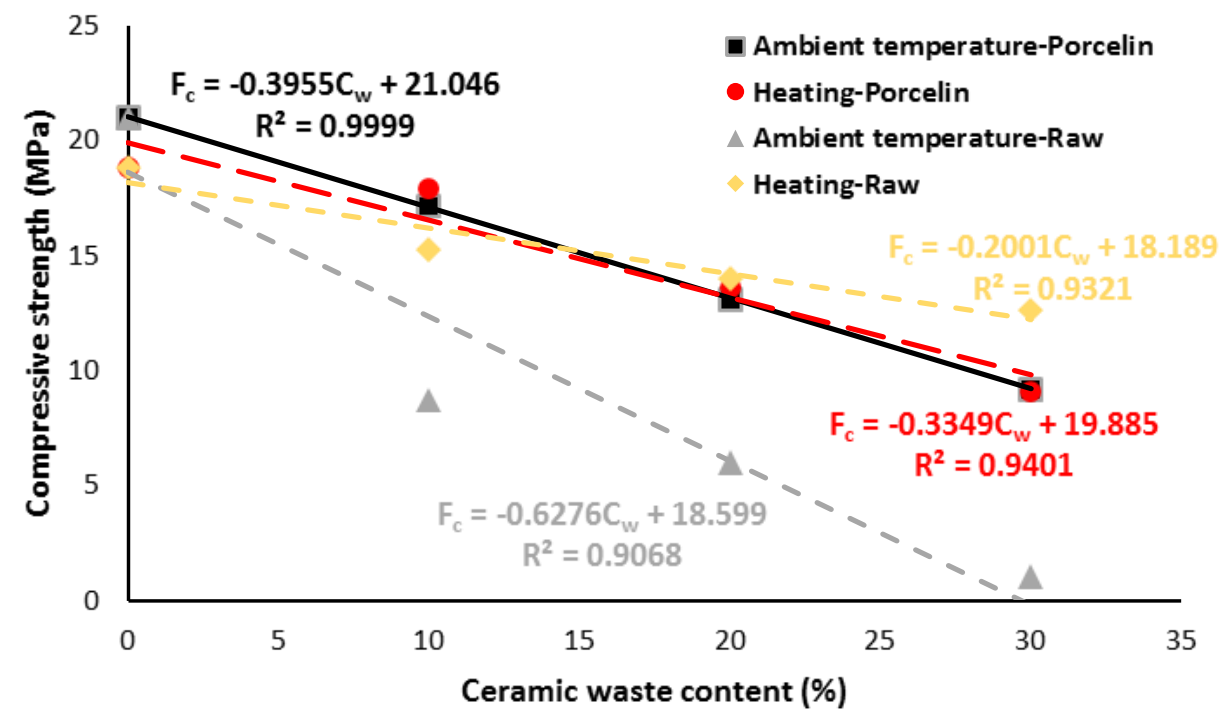

a) 7 days

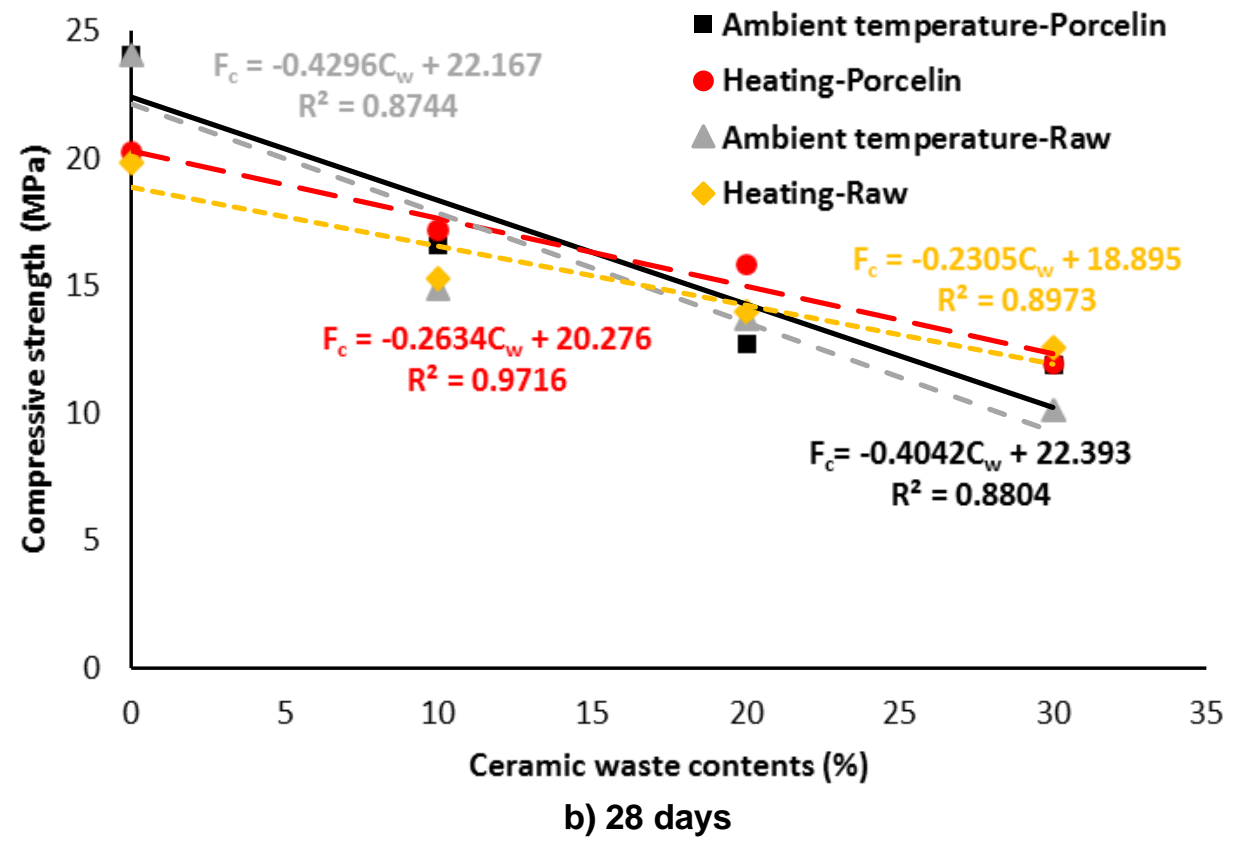

Fig 4. Correlation between strength and ceramic waste content of the specimens cured for: a) 7 days; b) 28 days.

Based on the results, a higher correlation was noticed between the strength and the ceramic waste in compositions containing porcelain compared to raw ceramic.

Furthermore, linear equations were derived to correlate the compressive strength and the ceramic waste at the final age. Comparing the equations at the early and final ages revealed a higher correlation between compressive strength and the ceramic waste at the early age compared to 
the final age. Interestingly, regardless of the early or final age, the maximum and minimum rates of strength loss due to replacement of slag with ceramic waste were obtained for the compositions containing raw ceramic wastes cured at the ambient conditions and thermal curing, respectively.

\section{Microstructural analysis}

\section{SEM/EDX analysis}

An SEM/EDX analysis was performed as a surface analytical technique to assess the differences in chemical reactions and products of different mix compositions. The morphologies of the alkaliactivated compositions, which were cured for 28 days, are shown in Figs 5 and 6 . Regarding the SEM/EDX analysis in Figs $5 \mathrm{a}$ and $5 \mathrm{~b}$, heating of the reference composition led to an increase in the calcium content and silica, and sodium levels decreased. Fig. 7 represents the $\mathrm{SiO}_{2} / \mathrm{Al}_{2} \mathrm{O}_{3}$ vs. $\mathrm{CaO} / \mathrm{SiO}_{2}$ molar ratios for gels participating in the binders (Garcia-Lodeiro et al. 2011; GarciaLodeiro et al. 2015; Pardal et al. 2009).
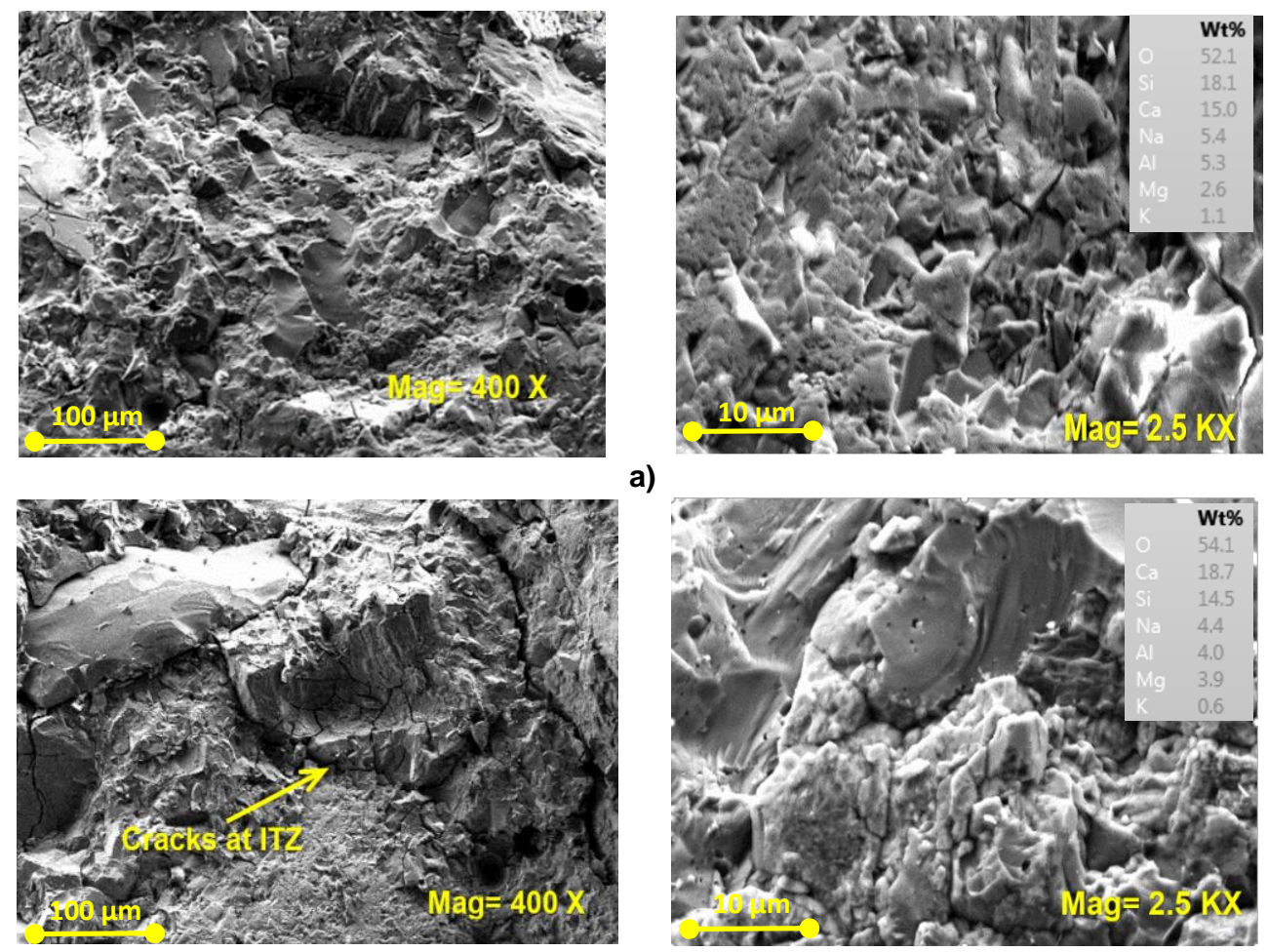

a)

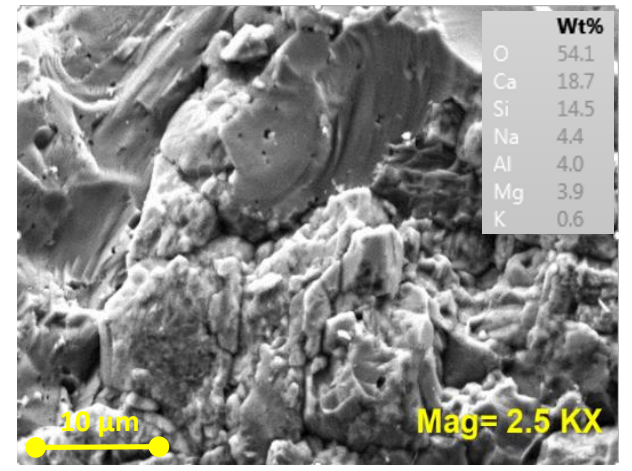

b)

Fig 5. Different magnifications of SEM images for the reference compositions cured: a) at the ambient conditions; b) using thermal curing. 

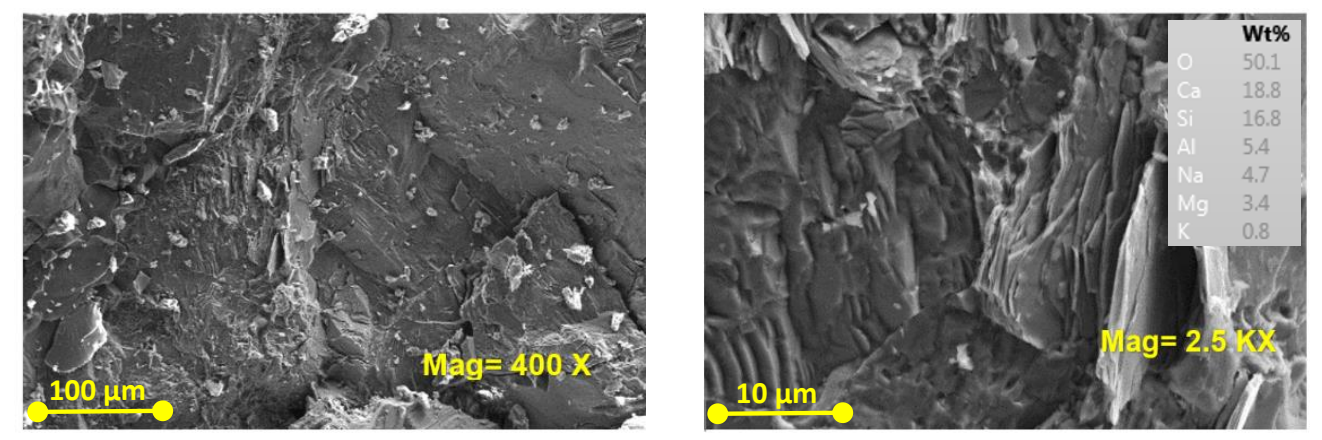

a)
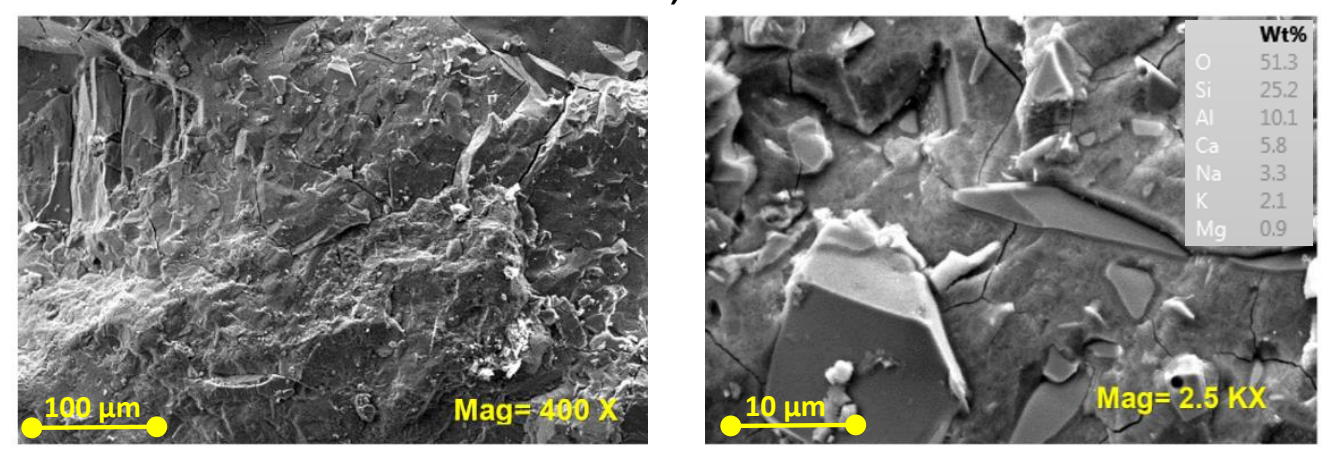

b)
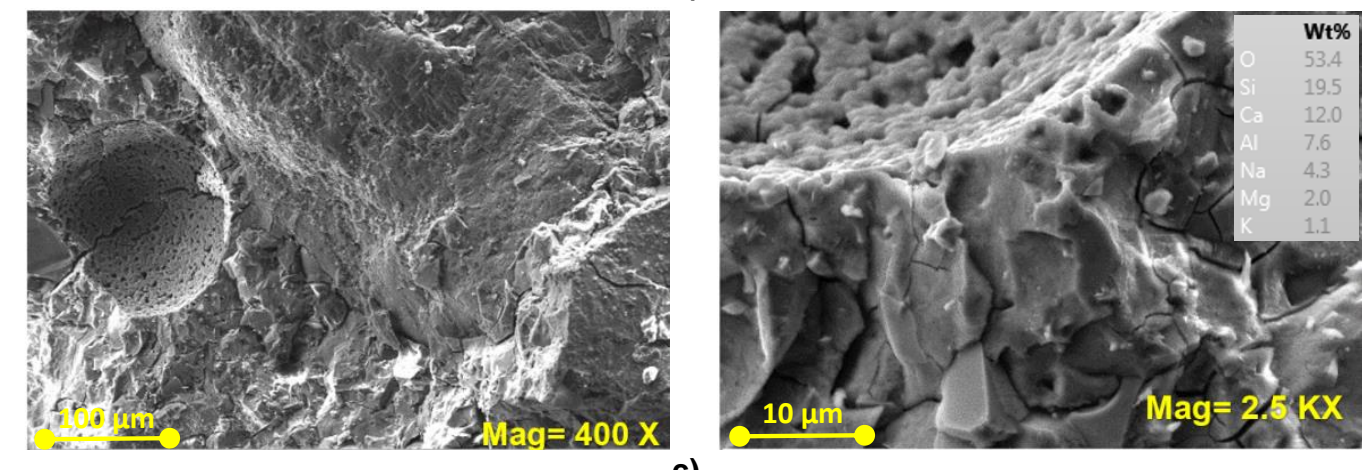

c)
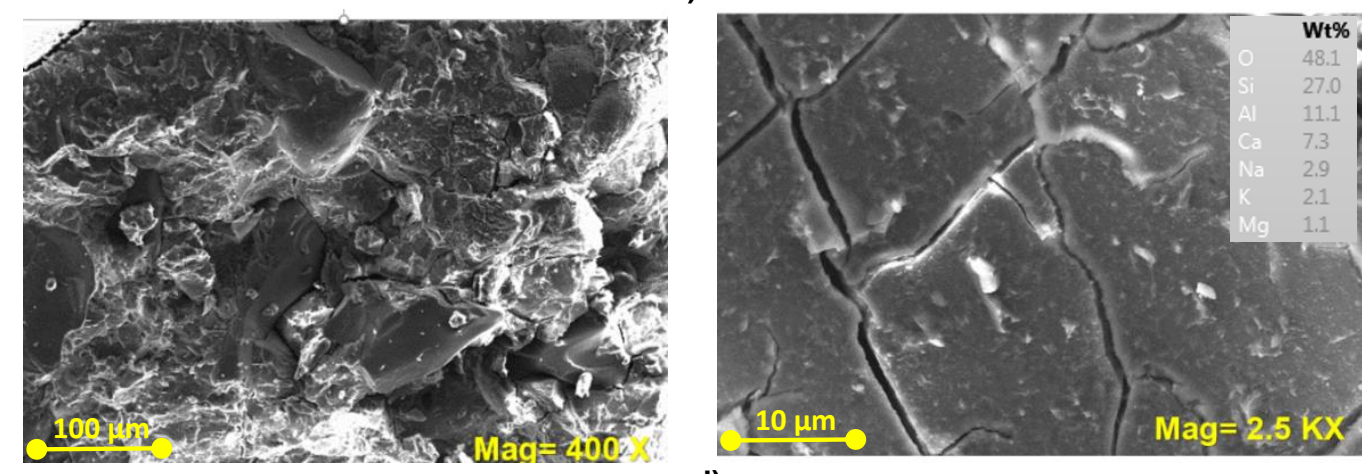

d) 

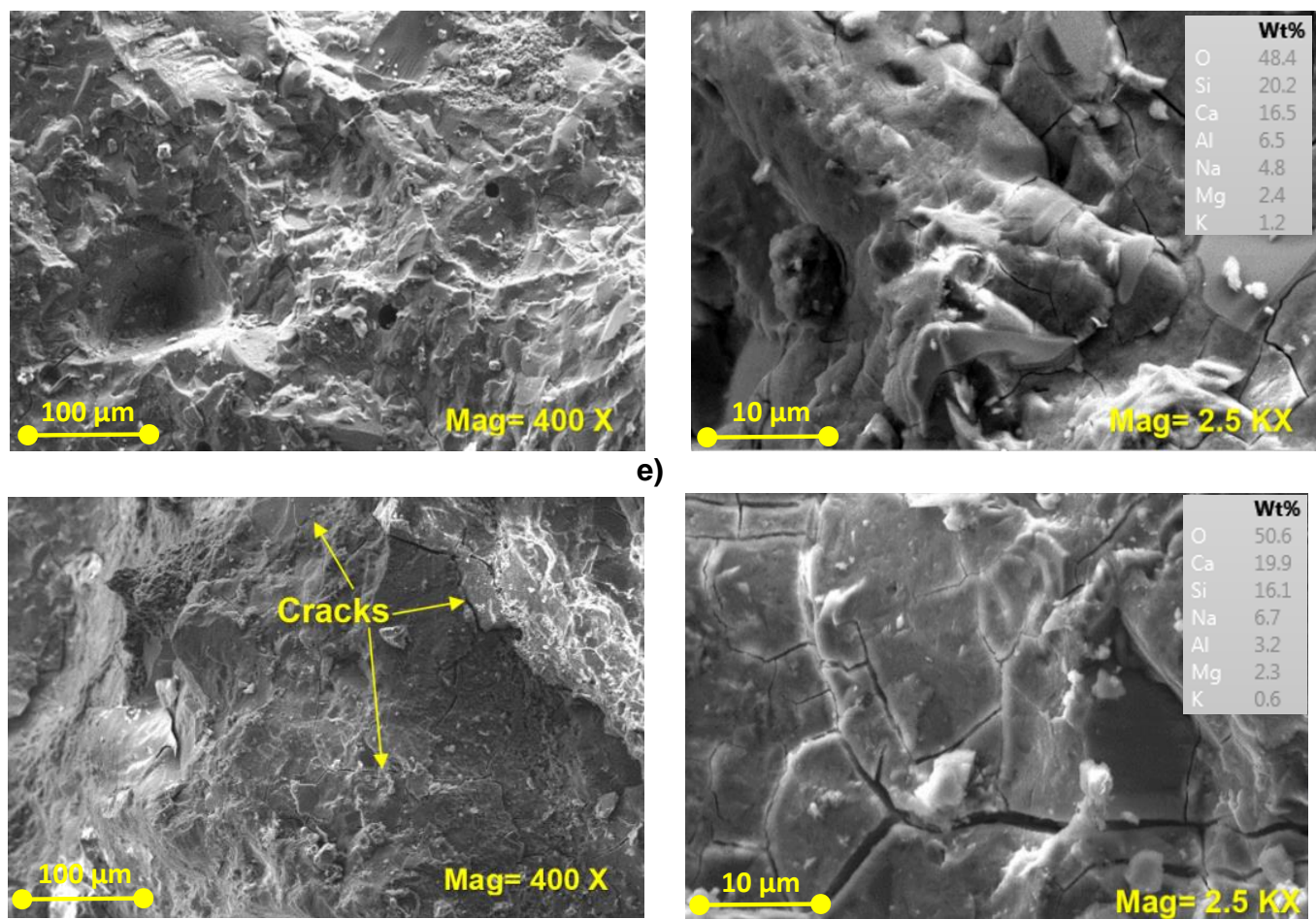

e)

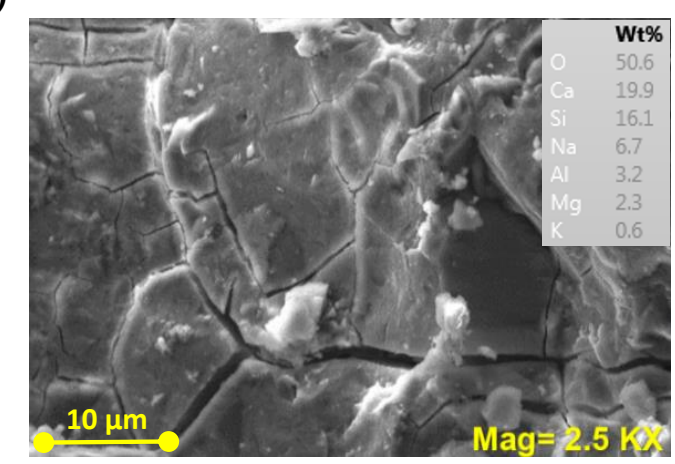

Fig 6. Different magnifications of SEM images for the mix compositions containing: a) $10 \%$ porcelain ceramic waste and heated; b) $10 \%$ porcelain ceramic waste and cured at the ambient temperature; c) $10 \%$ raw ceramic waste and heated; d) $10 \%$ raw ceramic waste and cured at the ambient temperature; e) $20 \%$ porcelain ceramic waste and heated; f) $20 \%$ porcelain ceramic waste and cured at the ambient temperature.

Based on the EDX analysis in Table 4 and Fig. 7, heating led to increasing the $\mathrm{CaO} / \mathrm{SiO}_{2}$ molar ratio, while the $\mathrm{SiO}_{2} / \mathrm{Al}_{2} \mathrm{O}_{3}$ molar ratio was almost constant. The chemical reactions were expected to enhance strength due to introducing heat to the specimens. Using thermal curing accelerates the chemical reactions through increase of the dissolution rates of silicate and aluminate species, which this could affect the molar ratios of $\mathrm{CaO} / \mathrm{SiO}_{2}$ and $\mathrm{SiO}_{2} / \mathrm{Al}_{2} \mathrm{O}_{3}$ (Suwan and Fan 2017; Peng et al. 2017). It was noticed in the SEM images that using thermal curing resulted in the formation of some cracks in the matrix and interfacial transition zone (ITZ) between the matrix and aggregate (see Fig. 5b). Therefore, a reduction was recorded in the strength of the reference mixture exposed to thermal curing compared to the specimens cured at the ambient conditions. Regarding the results, the calcium aluminum silicate hydrates (C-A-S-H) gel was formed as chemical reaction products in most compositions. However, in some compositions, Ca was replaced by $\mathrm{Na}$, and $(\mathrm{C}, \mathrm{N})-\mathrm{A}-\mathrm{S}-\mathrm{H}$ gels formed. 
Table 4. The EDX atomic ratio analysis.

\begin{tabular}{|c|c|c|c|c|c|}
\hline Mixture & $\mathrm{SiO}_{2} / \mathrm{Al}_{2} \mathbf{O}_{3}$ & $\mathrm{Al}_{2} \mathrm{O}_{3} / \mathrm{Na}_{2} \mathbf{O}$ & $\mathrm{CaO} / \mathrm{SiO}_{2}$ & $\mathrm{Na}_{2} \mathrm{O} / \mathrm{CaO}$ & $\mathrm{MgO} \mathrm{Al}_{2} \mathrm{O}_{3}$ \\
\hline Ref N & 6.83 & 0.84 & 0.56 & 0.31 & 1.09 \\
\hline Ref T & 6.98 & 0.23 & 0.70 & 0.90 & 2.17 \\
\hline 10FT & 5.99 & 0.98 & 0.78 & 0.22 & 1.40 \\
\hline 10F & 3.25 & 4.29 & 0.13 & 0.55 & 0.08 \\
\hline 10UT & 4.94 & 1.50 & 0.43 & 0.31 & 0.59 \\
\hline 10U & 4.68 & 3.26 & 0.19 & 0.35 & 0.22 \\
\hline 20FT & 5.98 & 1.15 & 0.57 & 0.25 & 0.49 \\
\hline 20F & 5.69 & 0.90 & 0.67 & 0.29 & 0.63 \\
\hline 20U & 7.58 & 0.66 & 0.44 & 0.45 & 0.56 \\
\hline
\end{tabular}

Fig. 6 shows the morphology of the matrices in which slag was replaced with ceramic wastes and matrices experienced different curing regimes. It was observed that using thermal curing conditions resulted in observing the smaller crack widths and reducing the number of cracks per unit area. This observation is in the line of strength developments. Reig et al. demonstrated in their investigations that ceramic as a precursor contributes to the chemical reactions and subsequently affects the mechanical strength (Reig et al. 2013).

The results in Fig. 7 (based on EDX findings) show that the compositions containing porcelain ceramic wastes mainly influence the molar ratio of $\mathrm{CaO} / \mathrm{SiO}_{2}$ and have a minor impact on the molar ratio of $\mathrm{SiO}_{2} / \mathrm{Al}_{2} \mathrm{O}_{3}$. An inverse trend was observed for the compositions containing raw ceramic wastes. This means that replacement of slag with raw ceramic waste had a major effect on the molar ratio of $\mathrm{SiO}_{2} / \mathrm{Al}_{2} \mathrm{O}_{3}$. This difference impacted the mechanism of strength gain. The molar ratio of $\mathrm{SiO}_{2} / \mathrm{Al}_{2} \mathrm{O}_{3}$ affects the substantial amount of $\mathrm{Ca}^{2+}$ is dissolved from the solid source material. When the concentration of silicate species is high, more silicate species are available to condense the gel instead of with aluminate species, so that the condensation rate between silicate species is slower than that between silicate and aluminate species (De Silva et al. 2007). In high calcium alkali activated systems, both sodium aluminate silicate hydrate (N-A-S-H) and the calcium aluminate silicate hydrate (C-A-S-H) gels are formed, which depends on the content of calcium through ion-exchange one of these gel type become dominate (Provis and van Deventer 2009).

Furthermore, for the mix composition with porcelain and raw ceramic wastes, it was confirmed by examining the micrographs (Fig. 6) that the formed matrices were not compacted, which would explain their lower strength compared to the reference mix composition.

Comparing the results in Figs. $6 \mathrm{c}$ and $6 \mathrm{~d}$ revealed that heating provided a denser matrix containing $10 \%$ raw ceramic waste compared to the matrix cured at the ambient conditions. 
Additionally, the EDX analysis showed that the molar ratios of $\mathrm{SiO}_{2} / \mathrm{Al}_{2} \mathrm{O}_{3}$ and $\mathrm{CaO} / \mathrm{SiO}_{2}$ increased due to the employment of thermal curing, which justified a slight improvement in the compressive strength compared to the ambient conditions.

Fig. 6 shows that replacing the $20 \%$ porcelain ceramic waste led to the formation of cracks in the matrix, which could have been formed due to the contraction stress between the ceramic waste particles and developing gels. As indicated in Fig. 6e, heating (due to the use of thermal curing) led to accelerating the chemical reactions and eliminating the cracks. This can be explained by the strength enhancement using the thermal curing regime.

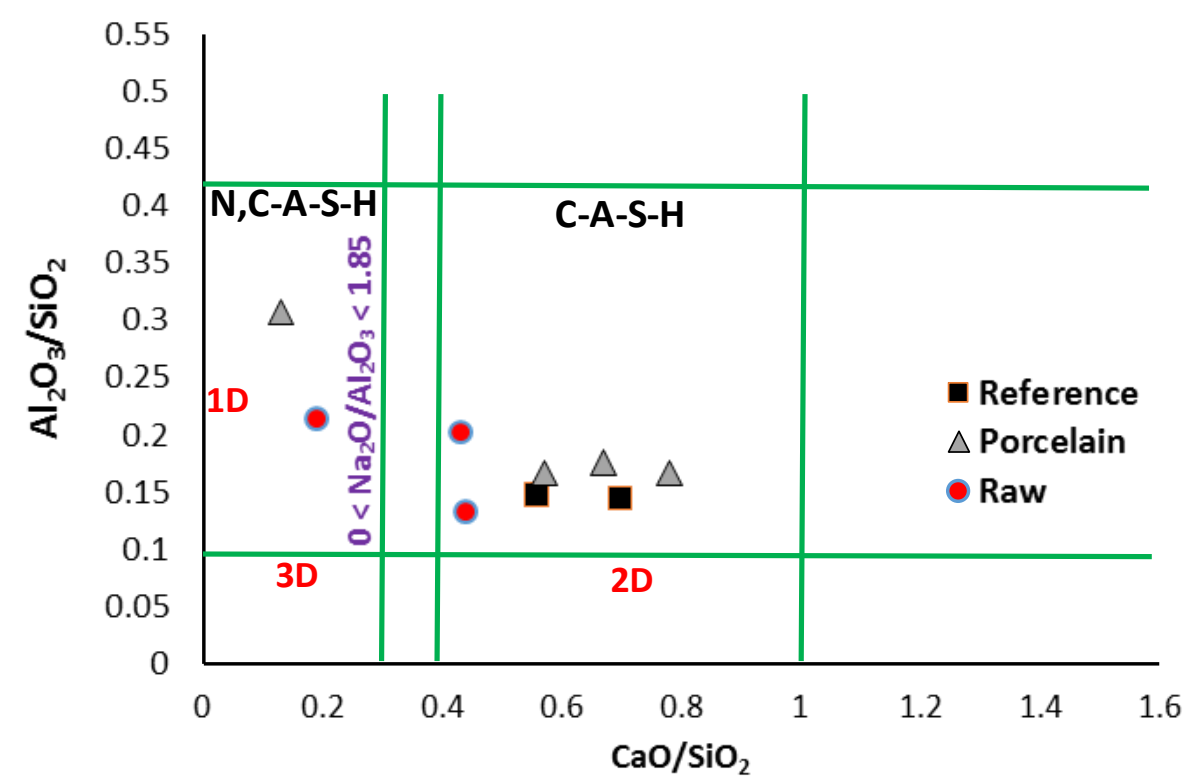

Fig 7. $\mathrm{Al}_{2} \mathrm{O}_{3} / \mathrm{SiO}_{2}$ vs. $\mathrm{CaO} / \mathrm{SiO}_{2}$ ratios for gels participating in the binders (based on EDX findings).

\section{Mineralogical alteration by an XRD analysis}

Fig. 8 shows the XRD diffractograms of the compositions with two different ceramic wastes, which were exposed to two different curing regimes at the final age (28 days). Regarding the results, a broad diffraction hump appears starting from $25^{\circ}(2 \theta)$ and ending around $35^{\circ}(2 \theta)$ in each pattern. In general, the major crystalline phases were quartz $\left(\mathrm{SiO}_{2}\right)$, mullite $\left(\mathrm{Al}_{2.35} \mathrm{Si}_{.64} \mathrm{O}_{4.82}\right)$, and albite $\left(\mathrm{NaAISi}_{3} \mathrm{O}_{8}\right)$. Some peaks of dioptase black $\left(\mathrm{CuSiO}_{3}\right)$, and kaolinite $\left(\mathrm{Al}_{2} \mathrm{Si}_{2} \mathrm{O}_{5}(\mathrm{O} \mathrm{H})_{4}\right)$ were also detected in the reference mix composition, although their peaks were significantly less intense in the rest of the mix compositions. 


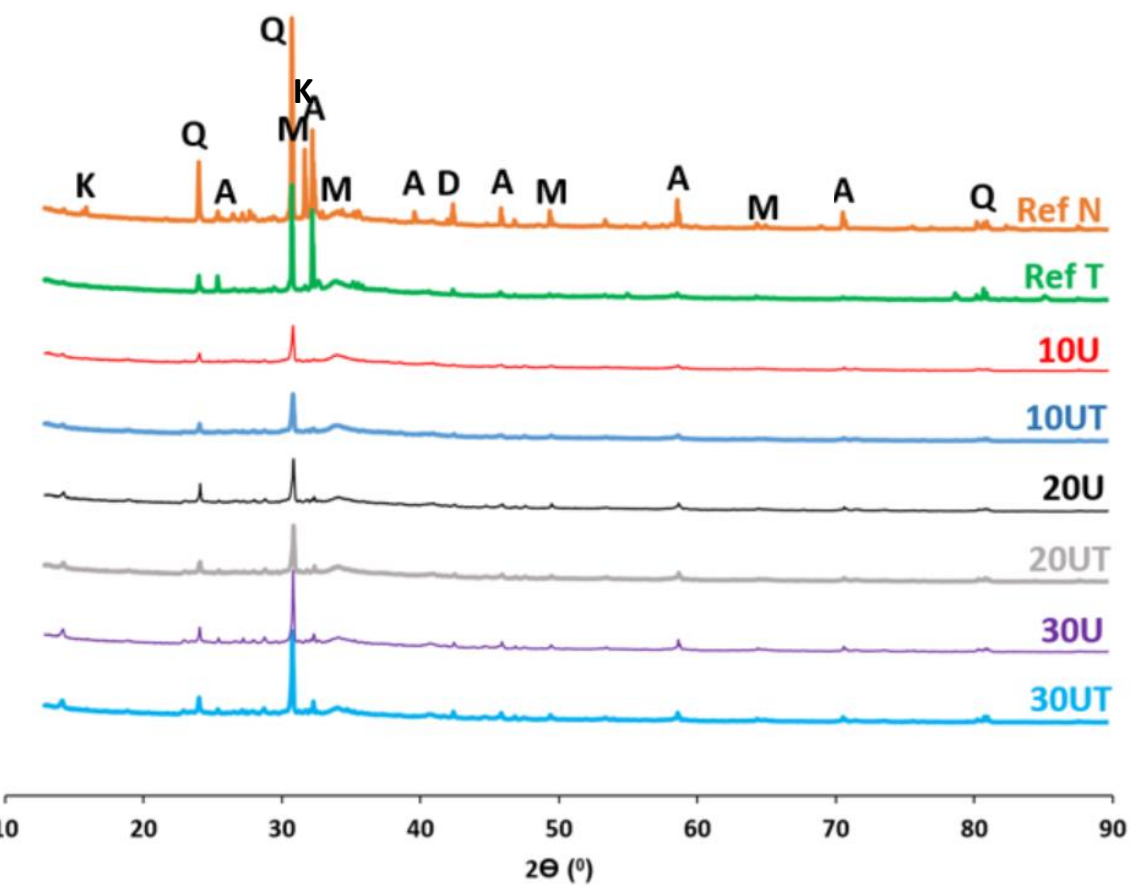

a)

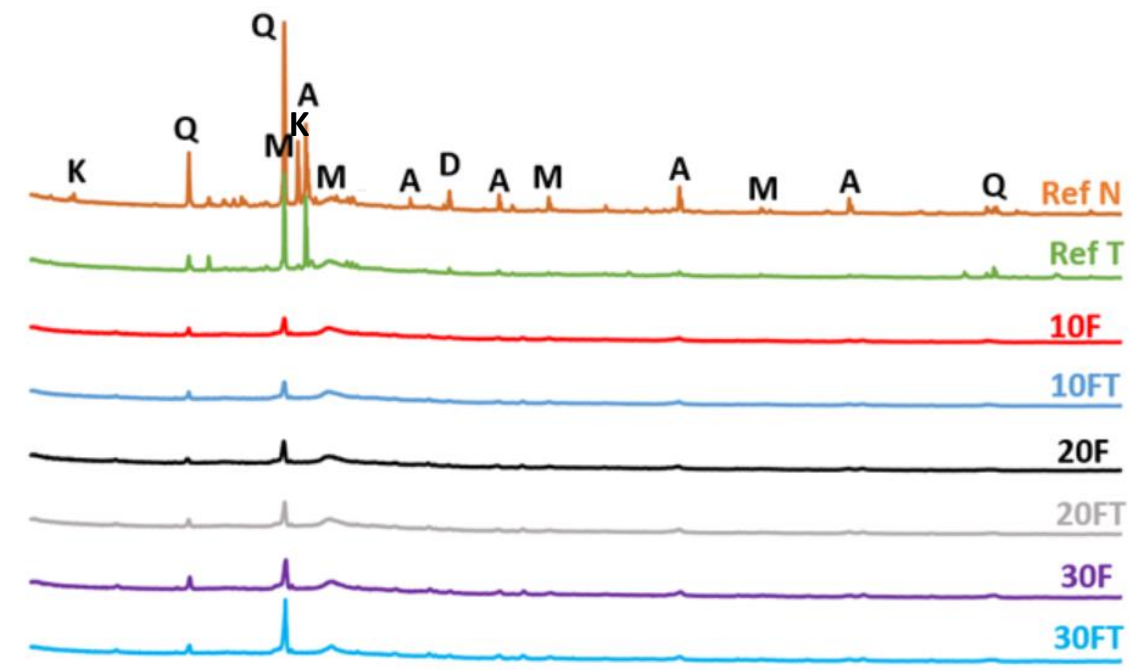

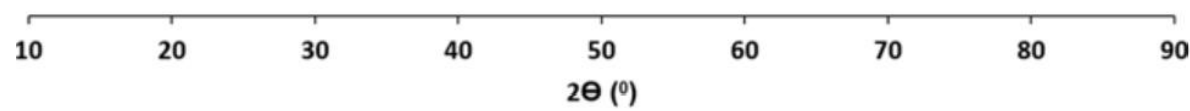

b)

Fig 8. XRD analysis for compositions use: a) raw ceramic waste; b) porcelain ceramic waste.

(Q-Quartz, D-Dioptase black, K-Kaolinite, A-Albite, and M-Mullite).

Moreover, the replacement of slag with ceramic waste resulted in a lower intensity of characteristic diffraction peaks, which means lower the crystalline phases were detected compared to the one-part alkali-activated slag-based binder. Using thermal curing leads to 
increasing the crystalline phases, which could be slightly deduced from the relatively flat diffractogram. The increase of the crystalline phases either improves or degrades the mechanical properties. The transition of amorphous gels into more ordered structures causes the local microstructure to change, introducing internal stresses. If enough space exists in the matrix to be filled with the formed crystalline phases, crystallization has no harmful effects on the strength (Ma et al. 2016). Regarding the strength development in the mixtures used thermal curing, the increase of the crystalline phases seems to have no harmful effect on the strength. Since there was a lack of space to grow the crystalline in the dense matrix of the reference mixture and the formation of the crystalline introduced internal stresses, therefore, it reduced the compressive strength. The findings in the XRD analysis were also in the line of the SEM/EDX analysis.

Comparing the characteristic diffraction peaks of the compositions shows that these peaks are broader. This means that higher crystallization phases were observed in the compositions containing raw ceramic wastes compared to the porcelain ceramic wastes. However, in general, the diffraction patterns of the compositions containing the ceramic wastes remained nearly constant as the curing regimes changed from ambient to thermal, indicating that the curing method did not change the mineralogical phases.

Fig. 9 represents the quantitative phase analysis, where the results are normalized to $100 \%$. With respect to the results, the major phase in the reference composition was Kaolinite (> $65 \mathrm{wt} . \%$ ). The compositions have similar phases, whereas the content was changed by replacing slag by ceramic wastes and using different curing conditions. By replacing slag with porcelain ceramic wastes (fired one), the quartz and mullite contents were increased and the Kaolinite content decreased (see Fig. 9a). This can explain the strength loss of the compositions containing ceramic wastes compared to the reference slag alkali-activated composition. As indicated in Fig. 9b, replacing 30\% slag with raw ceramic wastes (unfired) dramatically decreased the content of the Kaolinite phase (from $65 \%$ to $4 \%$ ) and increased the contents of both mullite $(\approx 6 \%$ to $42 \%$ ) and quartz ( $\approx 4 \%$ to $16 \%$ ). In general, it can be concluded that using raw ceramic wastes dramatically reduces the content of the Kaolinite phase. 


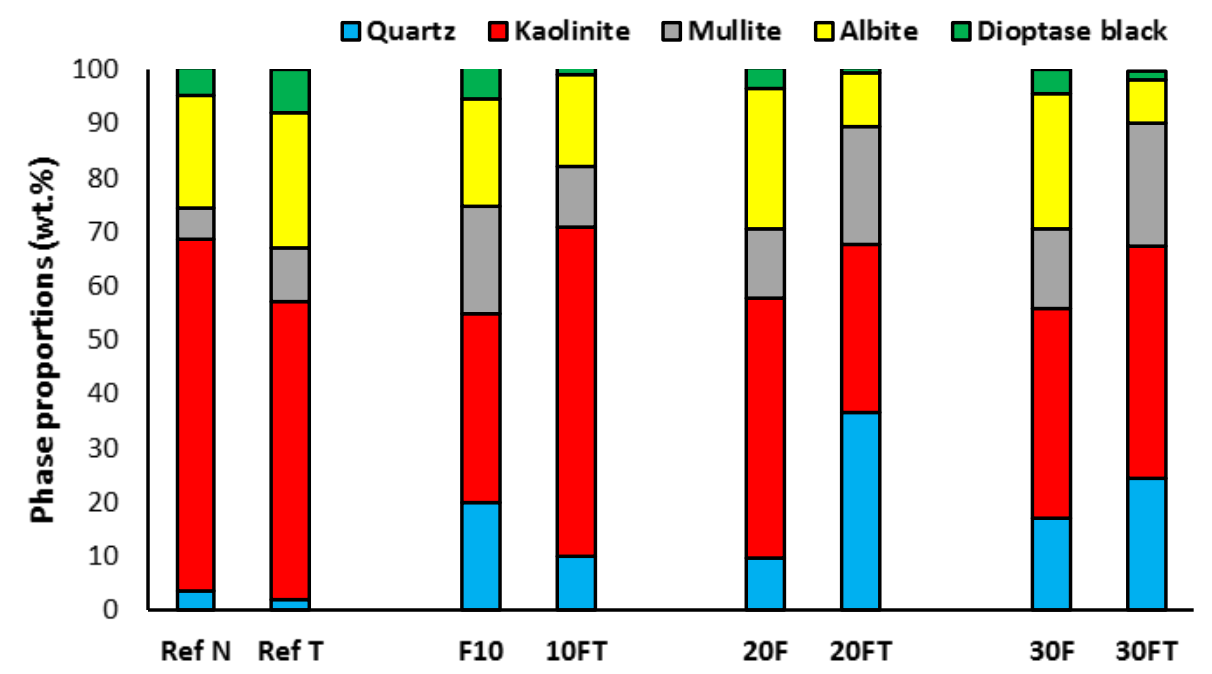

a)

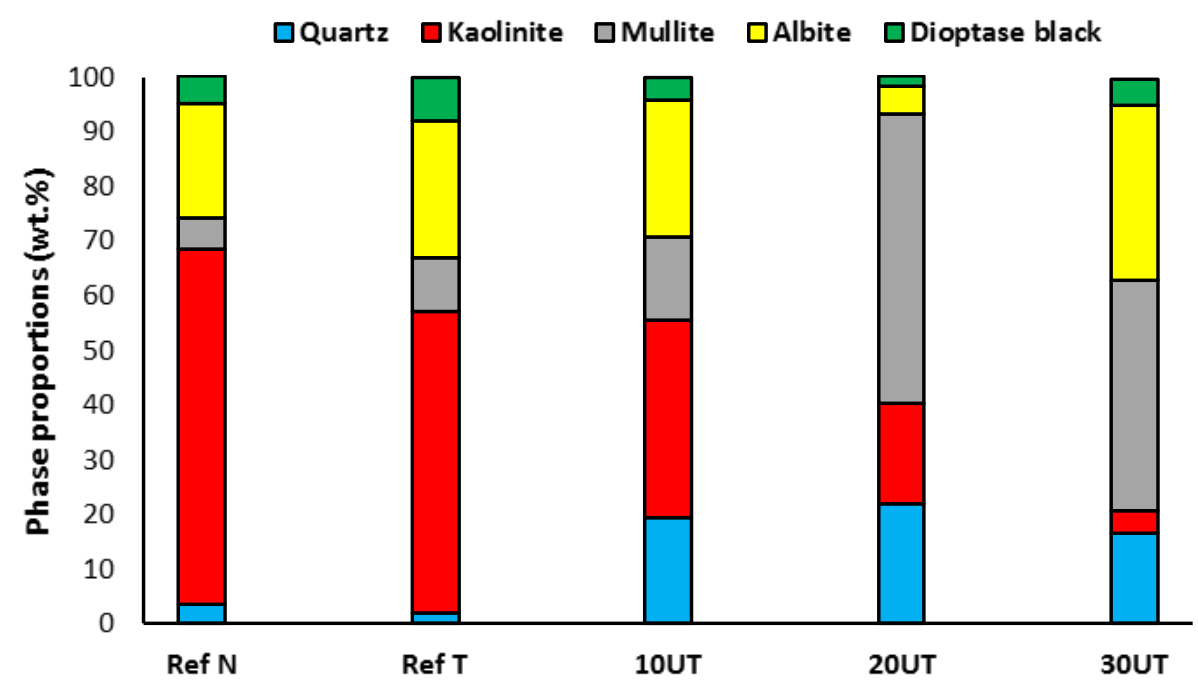

b)

Fig 9. Quantitative phase analysis of the compositions by the Rietveld method: a) raw ceramic waste; b) porcelain ceramic waste.

\section{Thermogravimetric analysis (TGA) and differential thermogravimetry (DTG)}

The thermogravimetric (TGA) and differential thermogravimetry (DTG) curves of the one-part alkali-activated ceramic/slag binders with an age of 28 days are represented in Fig. 10.

Figs 10a and 10c show the weight loss incorporation with increasing temperatures for different mixtures containing porcelain ceramic wastes by employing a thermogarvimetric analysis (TGA). In addition, differential thermogravimetry (DTG) of the slag/ceramic binders are presented in Figs $10 \mathrm{~b}$ and $10 \mathrm{~d}$, where detectable peaks occurring at different temperatures are defined. 
Weight losses in TGA were considered in temperatures between $100^{\circ} \mathrm{C}$ and $800^{\circ} \mathrm{C}$ ( Li et al. 2017). At the first stage, both free water and structurally bonded water are available in the composition. Then, the free water could be evaporated up to $100^{\circ} \mathrm{C}$ temperature, and the weight loss from $100^{\circ} \mathrm{C}$ to $800^{\circ} \mathrm{C}$ is attributed to the structural water (Nath et al. 2016).

The structural water loss can be seen as an estimation of the reaction product and the structure stability as the structural water was bonded in the reaction product, namely C-A-S-H gel. This higher mass loss may be associated with the presence of more chemically bounded water $(\mathrm{OH})$ group in the samples.

According to the results in Fig. 10, the composition with lower ceramic waste as a replacement of slag contained a larger amount of the hydration products and exhibited better structural stability when compared to the composition with a higher amount of ceramic wastes. Moreover, regarding the results, a weight loss around of $17 \%$ was observed in the reference composition cured at the ambient conditions, while a weight loss of about $15 \%$ was obtained for this composition cured by a thermal regime. This means that more chemical products were formed in the composition cured at the ambient conditions.

Regarding the DTA curves, two major endothermic peaks were observed at around $130^{\circ} \mathrm{C}$ and $200^{\circ} \mathrm{C}$. The large shoulder just below $200^{\circ} \mathrm{C}$ is attributed to the dehydration of the calcium-rich silicate gel (Alarcon-Ruiz et al. 2005). The differences in the major endothermic peaks of the DTA curves indicate that some additional gel formation may have occurred owing to the formation of a more ordered gel structure. The results also showed that the thermal curing condition impacted the endothermic peaks and the formation of extra gel in the compositions. This result is in agreement with results obtained from the XRD analysis and the SEM/EDX analysis.

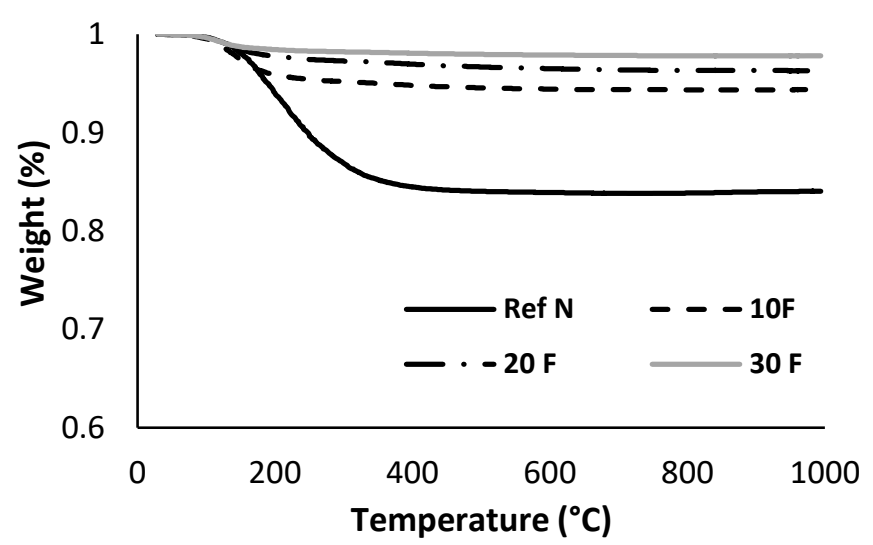

a)

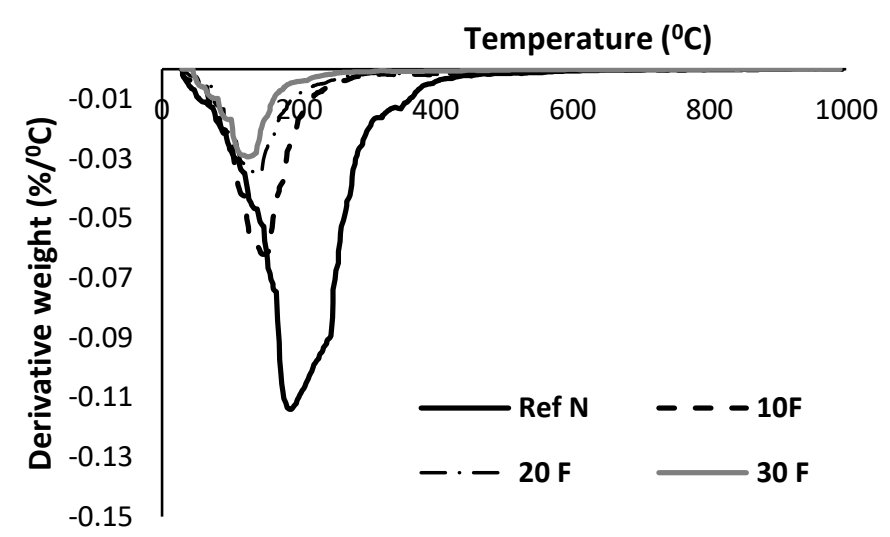

b) 


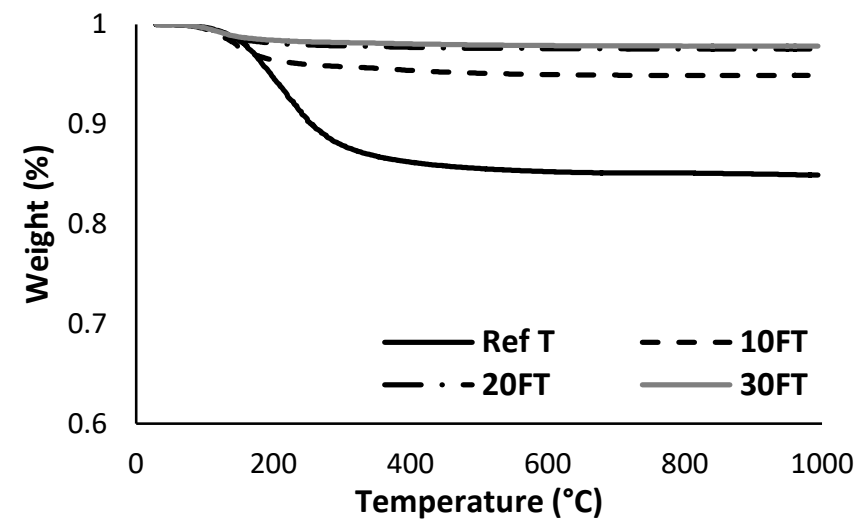

c)

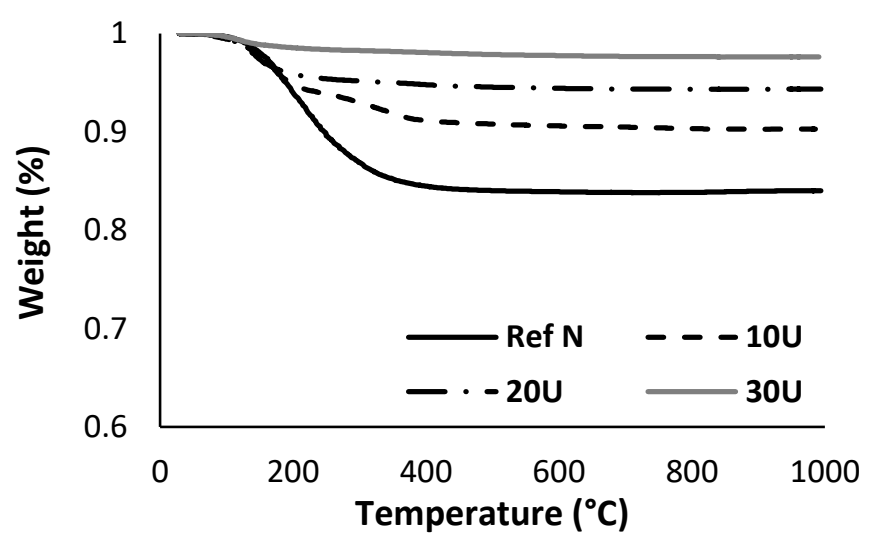

e)

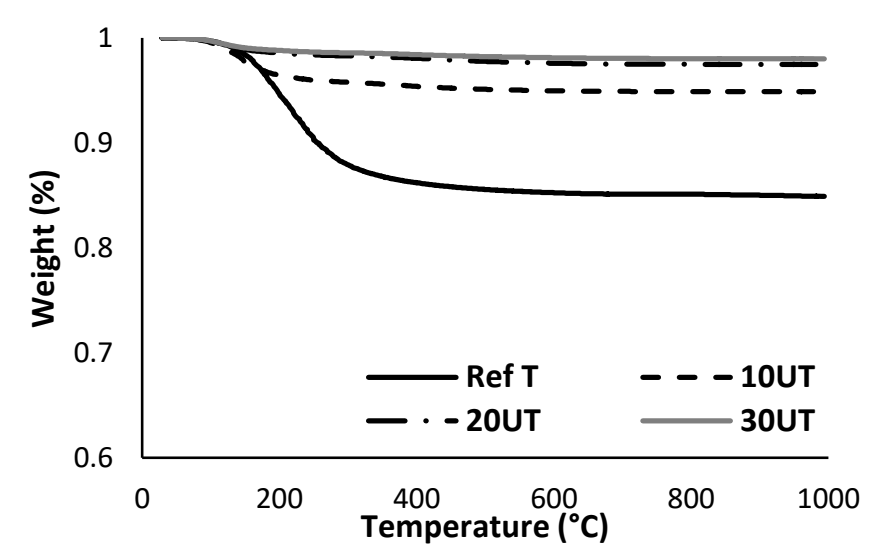

g)

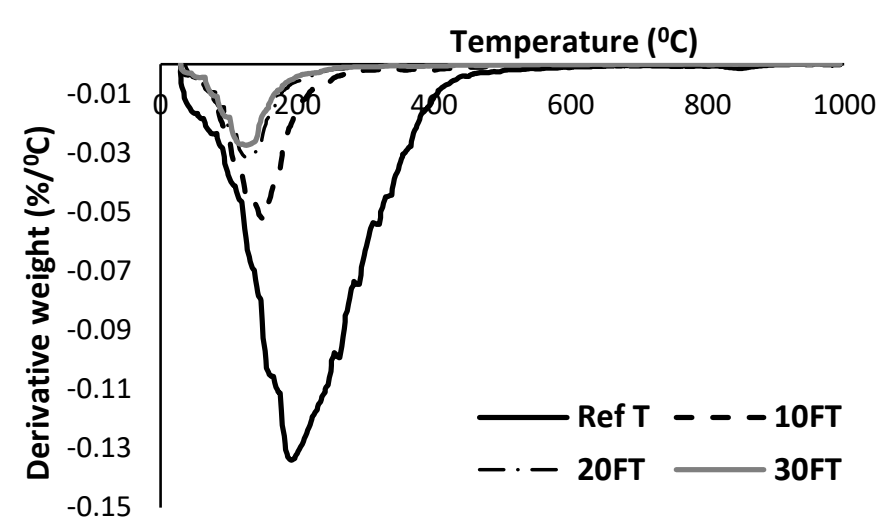

d)

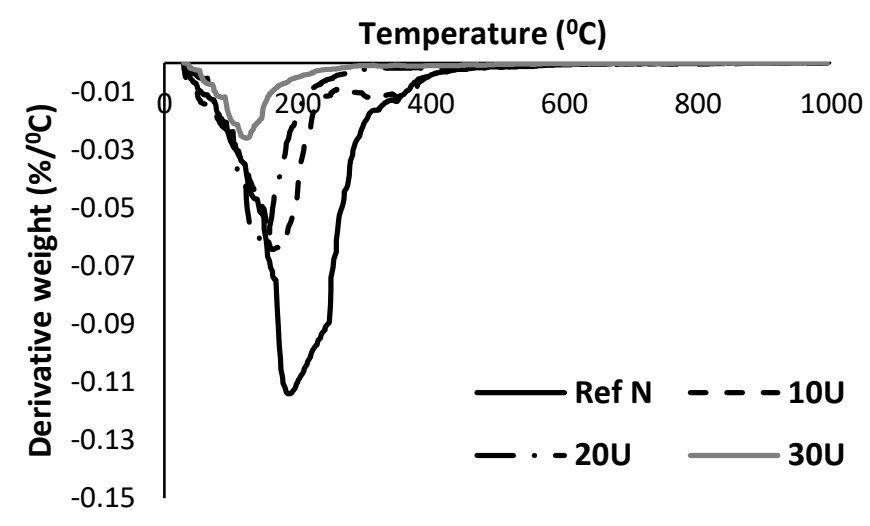

f)

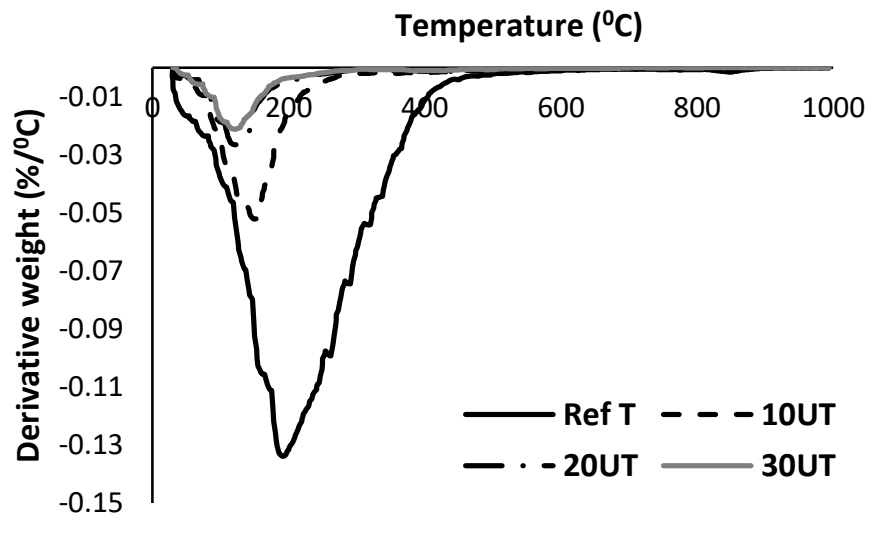

h)

Fig 10. a) TGA analysis; b) DTA analysis of the composition containing porcelain ceramic waste and cured at the ambient conditions; c) TGA analysis; d) DTA analysis of the composition containing porcelain ceramic waste and cured under thermal conditions; e) TGA analysis; f) DTA analysis of the composition containing raw ceramic waste and cured at ambient conditions; g) TGA analysis; h) DTA analysis of the composition containing raw ceramic waste and cured under thermal conditions. 


\section{A general model to correlate the strength and chemical compositions}

To optimize the chemical composition to achieve the maximum compressive strength, the effects of different elements ( $\mathrm{Ca}, \mathrm{Si}, \mathrm{Al}$, and $\mathrm{Na}$ ) were investigated.

The molar ratios $\left(\mathrm{CaO} / \mathrm{SiO}_{2}, \mathrm{Al}_{2} \mathrm{O}_{3} / \mathrm{SiO}_{2}\right.$, and $\left.\mathrm{Al}_{2} \mathrm{O}_{3} / \mathrm{Na}_{2} \mathrm{O}\right)$ of different mixtures, which were calculated and listed in Table 4, were used to correlate the strength and composition. The correlation between the strength and mix compositions was established for the molar ratio combination of $\mathrm{Ca}-\mathrm{Na}-\mathrm{Al}$ using a ternary diagram in OriginLab software. The molar ratio combination was normalized to $\mathrm{Si}$ in terms of the molar content. This approach was also used in the previous studies to design the alkali-activated cements based on their compressive strength $[35,36]$. With respect to the results in Fig. 11, high compressive strength (from 22 to $24 \mathrm{MPa}$ ) could be obtained in the compositions with molar ratios in the ranges of $60 \%-65 \% \mathrm{Ca} / \mathrm{Si}$ ( $\left.\frac{\left(\frac{C a}{S i}\right)}{\left(\left(\frac{C a}{S i}\right)+\left(\frac{N a}{S i}\right)+\left(\frac{A l}{S i}\right)\right)}=\frac{C a}{(C a+N a+A l)}\right) ; 20 \%-25 \% \mathrm{Na} / \mathrm{Si}\left(\frac{N a}{(C a+N a+A l)}\right) ;$ and $15 \%-20 \%$

Al/Si $\left(\frac{A l}{(C a+N a+A l)}\right)$. Regarding the results obtained from the ternary diagrams, it could be concluded that the molar ratio of $\mathrm{Ca} / \mathrm{Si}$ had the greatest impact on the strength of the one-part alkali activated ceramic/slag binders. Afterward, the highest effects of molar ratios on the strength could be sorted into the following order: $\mathrm{Na} / \mathrm{Si}$, and $\mathrm{Al} / \mathrm{Si}(\mathrm{Ca} / \mathrm{Si}>\mathrm{Na} / \mathrm{Si}>\mathrm{Al} / \mathrm{Si})$. Since the $\mathrm{CaO}$ was sourced from slag, it means that the slag content had a dominant effect on the strength of the compositions. This finding is confirmed by previous studies ( $\mathrm{Li}$ et al. 2017; Samson et al. 2017).

The applications of the materials are defined based on their strengths. The developed mortars can be classified as controlled low-strength materials, which are not structural materials, so they cannot be called concrete. These are the cementitious materials, which are mainly used as fill materials for construction applications such as bridge abutment (Kuo et al. 2013; Alizadeh et al. 2014).

\section{Conclusions}


This experimental investigation exhibited the feasibility of using ceramic waste as both a precursor and a recycled fine aggregate in a one-part alkali-activated material. Two different types of ceramic wastes, fired and unfired, were used as a partial replacement for ground granulated blastfurnace slag. Simultaneously, coarsely sized waste ceramic was used as recycled fine aggregate in all mix compositions. All efforts in this study aimed to maximize the use of ceramic waste in one-part alkali-activated ceramic/slag binders. Furthermore, the effects of two curing regimes on the strength development and microstructure were investigated. The compressive strengths of different compositions were assessed at early ( 7 days) and final (28 days) ages. The microstructural analysis was used to evaluate the morphology and mineralogical phases of the mix compositions. Finally, a general model to correlate the strength and molar ratios of the mix compositions was established using a ternary system. With respect to the experimental study reported herein, the following results can be highlighted:

1. At the final age, the compressive strength was lowered as the precursor was replaced with porcelain ceramic waste up to $20 \%$, while using $100 \%$ porcelain ceramic waste as recycled fine aggregate. Further replacement had no impact on the strength loss of the specimens cured at the ambient conditions up to $30 \%$.

2. Regarding the analytical results, the maximum and minimum rates of strength loss were measured in the mix compositions containing raw ceramic wastes and cured under ambient and thermal conditions, respectively.

3. Due to the increase of curing time from 7 to 28 days, the maximum improvement in strength (almost 10 times) was recorded in the mix composition containing 30\% raw ceramic waste and cured in the ambient conditions.

4. The use of thermal curing led to measuring the maximum improvement of strength (more than 6 times) at the early age in the composition containing 30\% raw ceramic wastes.

5. The morphology of the matrices indicated that using thermal curing conditions in the mix compositions containing both slag and ceramic wastes resulted in observing the smaller crack widths and reducing the number of cracks per unit area.

6. The quantitative phase analysis showed that the compositions have similar phases, whereas the content was changed by replacing slag by ceramic wastes and using different curing conditions. Additionally, it was revealed that using raw ceramic wastes dramatically reduces the content of the Kaolinite phase.

7. The mineralogical studies showed that the use of thermal curing can increase the crystalline phases. 
8. The detected endothermic peaks in the DTA curves were attributed to the dehydration of the calcium-rich silicate gel.

9. Using a ternary system, the molar ratio of $\mathrm{Ca} / \mathrm{Si}$ had the greatest impact on the strength of the binders.

\section{Acknowledgements}

This study was carried out by the project (GEOBIZ) grant ID: 1105/31/2016 and financially supported by the Finnish Funding Agency for Technology and Innovation (Tekes).

\section{References}

Abdollahnejad, Z., Kheradmand, M., and Pacheco-Torgal, F. (2017). "Short-term compressive strength of fly ash and waste glass alkali-activated cement based binder (AACB) mortars with two biopolymers." Journal of Materials in Civil Engineering (ASCE), Vol. 29, Issue 7, https://doi.org/10.1061/(ASCE)MT.1943-5533.0001920.

Akçaözoglu, S., and Ulu, C. (2014). "Recycling of waste PET granules as aggregate in alkaliactivated blast furnace slag/metakaolin blends." Construction and Building Materials, Vol. 58, pp: 31-37.

Alarcon-Ruiz, L., Platret G., Massieu E., and Ehrlacher, A. (2005). "The use of thermal analysis in assessing the effect of temperature on a cement paste." Cement and Concrete Research, Vol. 35, pp: 609-613.

Alizadeh V., Helwany S., Ghorbanpoor A., and Sobolev K. (2014). "Design and application of controlled low strength materials as a structural fill." Construction and Building Materials, Vol. 53, pp: 425-431.

Altan, E., and Erdogan, S.T. (2012). "Alkali activation of a slag at ambient and elevated temperatures." Cement and Concrete Composites, Vol. 34, pp: 131-139.

Andrew, R. M. (2018). "Global $\mathrm{CO}_{2}$ emissions from cement production." Earth System Science Data, Vol. 10, pp: 195-217, https://doi.org/10.5194/essd-10-195-2018, 2018. 
Atis, C. D., Görür, E. B., Karahan, O., Bilim, C., Ilkentapar, S., and Luga, E. (2015). "Very high strength (120 MPa) class $\mathrm{F}$ fly ash geopolymer mortar activated at different $\mathrm{NaOH}$ amount, heat curing temperature and heat curing duration." Construction and Building Materials, Vol. 96, pp: 673-678.

ASTM C109 / C109M-16a, Standard Test Method for Compressive Strength of Hydraulic Cement Mortars, ASTM International, West Conshohocken, PA, 2016, www.astm.org.

Aydın, S., and Baradan, B. (2013). "The effect of fiber properties on high performance alkali activated slag/silica fume mortars." Composite part B: Engineering, Vol. 45, pp: 63-69.

Behera, M., Bhattacharyya, S.K., Minocha, A.K., Deoliya, R., and Maiti, S. (2014). "Recycled aggregate from $C \& D$ waste \& its use in concrete - A breakthrough towards sustainability in construction sector: a review." Construction Building Materials, Vol. 68, pp: 501-516.

Bernal, S.A., Gutierrez, R.M., Provis, J.L., and Rose, V. (2010). "Effect of silicate modulus and metakaolin incorporation on the carbonation of alkali silicate-activated slags." Cement and Concrete Research, Vol. 40, pp: 898-907.

Biolzi, L., Cattaneo, S., and Rosati, G. (2008). "Evaluating residual properties of thermally damaged concrete." Cement and Concrete Composites, Vol. 30, pp: 907-916.

Chen, X., Meawad, A., and Struble, L.J. (2014). "Method to stop geopolymer reaction." Journal of American Ceramic Society, Vol. 97, pp: 3270-3275.

De Silva, P., Sagoe-Crenstil, K., and Sirivivatnanon, V. (2007). "Kinetics of geopolymerization: role of $\mathrm{Al}_{2} \mathrm{O}_{3}$ and $\mathrm{SiO}_{2}$." Cement and Concrete Research, Vol. 37, pp: 512-518.

Eckert, M., and Oliveira, M. (2017). "Mitigation of the negative effects of recycled aggregate water absorption in concrete technology." Construction and Building Materials, Vol. 133, pp: 416-424.

Fernandes, M., Sousa, A., and Dias, A. (2004). "Environmental Impact and Emissions Trade Ceramic Industry, A case study." Portuguese Association of Ceramic Industry APICER. 
Frías, M., Rodríguez, O., Vegas, I., and Vigil, R. (2008). "Properties of calcined clay waste and its influence on blended cement behavior." Journal of the American Ceramic Society, Vol. 91, pp: 1226-30.

Garcia-Lodeiro, I., Palomo, A., Fernández-Jiménez, A., and Macphee, D.E. (2011). “Compatibility studies between N-A-S-H and C-A-S-H gels. Study in the ternary diagram $\mathrm{Na}_{2} \mathrm{O}-\mathrm{CaO}-\mathrm{Al}_{2} \mathrm{O}_{3}-$ $\mathrm{SiO}_{2}-\mathrm{H}_{2} \mathrm{O}$." Cement and Concrete Research, Vol. 41, pp. 923-931.

Garcia-Lodeiro, I., Fernández-Jimenez, A., and Palomo, A. (2015). "Cements with a low clinker content: versatile use of raw materials." Journal of Sustainable Cement-Based Materials, Vol. 4, pp: $140-151$.

GdE (Gobierno de España), (2011). Ministerio de Fomento de España, Catálogo de Residuos Utilizables en Construcción.

Gonçalves, J.P., Tavares, L.M., Toledo Filho, R.D., and Fairbain, E.M.R. (2009). "Performance evaluation of cement mortars modified with metakaolin or ground brick." Construction and Building Materials, Vol. 23, pp: 1971-9.

INE (Instituto Nacional de Estadística), (2013). Estadísticas Sobre Medio Ambiente. Encuesta Sobre Generación de Residuos en el Sector Servicios y Construcción.

Kim, H., and Kim, Y. (2013). "Relationship between compressive strength of geopolymers and pre-curing conditions." Applied Microscopy, Vol. 43, pp: 155-163.

Kuo, W., Wang, H., Shu, C., and Su, D. (2013). "Engineering properties of controlled low-strength materials containing waste oyster shells", Construction and Building Materials, Vol. 46, pp: 128133.

Lavat, A.E., Trezza, M.A., and Poggi, M. (2009). "Characterization of ceramic roof tile wastes as pozzolanic admixture." Waste Management, Vol. 29, pp: 1666-1674. 
Lee, H., Vimonsatit, V., and Chindaprasirt, P. (2016). "Mechanical and micromechanical properties of alkali activated fly-ash cement based on nano-indentation", Construction and Building Materials, Vol. 107, pp: 95-102.

Li, N., Shi, C., Wang, Q., Zhang, Z., and Ou, Z. (2017). "Composition design and performance of alkali-activated cements." Materials and Structures, Vol. 50, https://doi.org/10.1617/s11527-0171048-0.

Luukkonen, T., Abdollahnejad, Z., Yliniemi, J., Kinnunen, P., and Illikainen, M., (2018a). "Onepart alkali-activated materials: A review." Cement and Concrete Research, Vol. 103, pp: 21-34.

Luukkonen, T., Abdollahnejad, Z., Yliniemi, J., Kinnunen, P., and Illikainen, M., (2018b). "Comparison of alkali and silica sources in one-part alkali-activated blast furnace slag mortar." Journal of Cleaner Production, Vol. 187, pp: 171-179.

Ma, X., Zhang, Z., and Wang, A. (2016). "The transition of fly ash-based geopolymer gels into ordered structures and the effect on the compressive strength." Construction and Building Materials, Vol. 104, pp: 25-33.

Mas, M., Monzó, J., Payá, J., Reig, L., and Borrachero, M. (2015). "Ceramic tiles waste as replacement material in Portland cement." Advances in Cement Research, Vol. 28, pp: 1-12.

Ming, L., Young, H., Al Bakri, M., and Hussin, K. (2016). "Clay geopolymer cements: Structure and properties." Progress in Materials Science, 83, pp: 595-629.

Nath, S.K., Maitra, S., Mukherjee, S., and Kumar, S. (2016). "Microstructural and morphological evolution of fly ash based geopolymers." Construction and Building Materials, Vol. 111, pp: 758765.

Nuran, A., and Mevlut, U. (2000). "The use of waste ceramic tile in cement production." Cement and Concrete Research, Vol. 30, pp: 497-499.

Pacheco-Torgal, F., and Jalali, S. (2010). "Reusing ceramic wastes in concrete." Construction and Building Materials, Vol. 24, pp: 832-838. 
Pardal, X., Pochard, I., and Nonat, A. (2009). "Experimental study of Si-Al substitution in calciumsilicate-hydrate (C-S-H) prepared under equilibrium conditions." Cement and Concrete Research, Vol. 39, pp: 637-643.

Peng, M.X., Wang, Z.H., Xiao, Q.G., Song, F., Xie, W., Yu, L.C., Huang, H.W., and Yi, S.J. (2017). "Effects of alkali on one-part alkali-activated cement synthesized by calcining bentonite with dolomite and $\mathrm{Na}_{2} \mathrm{CO}_{3}$." Applied Clay Science, Vol. 139, pp: 64-71.

Pereira-de-Oliveira, L.A., Castro-Gomes, J.P., and Santos, P.M.S. (2012). "The potential pozzolanic activity of glass and red-clay ceramic waste as cement mortars components." Construction and Building Materials, Vol. 31, pp: 197-203.

Poon, C., and Chan, D. (2007). "The use of recycled aggregate in concrete in Hong Kong." Resources Conservation \& Recycling, Vol. 50, pp: 293-305.

Provis, J. L., and van Deventer, J. S. J. (2009). "Geopolymers: structure, processing, properties and industrial applications." Woodhead, Cambridge, UK.

Puertas, F., García-Díaz, I., Barba, A., Gazulla, M.F., Palacios, M., Gómez, M.P., and MartínezRamírez, S. (2008). "Ceramic wastes as alternative raw materials for Portland cement clinker production." Cement Concrete Composite, Vol. 30, pp: 798-805

Rahmani, T., Kiani, B., Shekarchi, M., and Safari, A. (2012). "Statistical and experimental analysis on the behavior of fiber reinforced concretes subjected to drop weight test." Construction and Building Materials, Vol. 37, pp: 360-369.

Reig, L., Tashima, M., Soriano, L., Borrachero, M V., Monzó, J., and Payá, J. (2013). "Alkaline Activation of Ceramic Waste Materials." Waste and Biomass Valorization, Vol. 4, pp: 729-736.

Reig, L., Sanz, M.A., Borrachero, M.V., Monzo, J., Soriano, L., and Paya, J. (2017). "Compressive strength and microstructure of alkali activated mortars with high ceramic waste content." Ceramics international, Vol. 43, pp: 13622-13634. 
Samson, G., Cyr, M., and Gao, X.X. (2017). "Formulation and characterization of blended alkaliactivated materials based on flash-calcined metakaolin, fly ash and GGBS." Construction and Building Materials, Vol. 144, pp: 50-64.

Sánchez De Rojas, M.I., Marín, F.P., Rivera, J., and Frías, M. (2006). "Morphology and properties in blended cements with ceramic wastes as a pozzolanic material." Journal of the American Ceramic Society, Vol.89, pp: 3701-5.

Sánchez De Rojas, M.I., Marín, F.P., Rivera, J., Escorihuela, M.J., and Marín, F. (2001). "Research about the pozzolanic activity of waste materials from calcined clay." Material Construction, Vol. 51, pp:45-52.

Sánchez De Rojas, M.I., Marín, F.R., Frías, M., and Rivera, J., (2007). "Properties and performances of concrete tiles containing waste fired clay materials." Journal of American Ceramic Society, Vol. 90, pp: 3559-65.

Senthamarai, R.M., and Devadas Manoharan, P. (2005). "Concrete with ceramic waste aggregate." Cement and Concrete Composites, Vol. 27, pp: 910-913.

Shi, C., Jiménez, A.F., and Palomo, A. (2011). "New cements for the 21st century: the pursuit of an alternative to Portland cement." Cement and Concrete Research, Vol. 41, pp: 750 - 763.

Shafiq, I., Azreen, M., and Hussin, M.W. (2017). "Sulphuric Acid Resistant of Self Compacted Geopolymer Concrete Containing Slag and Ceramic Waste." Materials Web of Conferences, Vol. 97, pp: 1-7.

Shaikh, F.A. (2016). "Mechanical and durability properties of fly ash geopolymer concrete containing recycled coarse aggregates." International Journal of Sustainable Built Environment, Vol. 5, pp: 277-287.

Silva, J., Brito, J., and Veiga, R. (2008). "Fine ceramics replacing cement in mortars partial replacement of cement with fine ceramics in rendering mortars." Material Structure, Vol. 41, pp: 1333-44. 
Suwan T., and Fan, M. (2017). "Effect of manufacturing process on the mechanisms and mechanical properties of fly ash-based geopolymer in ambient curing temperature." Materials and Manufacturing Processes, Vol. 32, pp: 461-467.

Toledo Filho, R.D., Gonçalves, J.P., Americano, B.B., and Fairbain, E.M.R. (2007). "Potential for use of crushed waste calcined-clay brick as a supplementary cementitious material in Brazil." Cement Concrete Research, Vol. 37, pp: 1357-65.

Toniolo, N., and Boccaccini, A.R. (2017). "Fly ash-based geopolymers containing added silicate waste. A review." Ceramics International, Vol. 43, pp: 14545-14551.

Turanli, L., Bektas, F., and Monteiro, P.J.M. (2003). "Use of ground clay brick as a pozzolanic material to reduce the alkali-silica reaction." Cement Concrete Research, Vol. 33, pp: 1539-42.

Vickers, L., Van Riessen, A.R., and William D.A. (2015). "Precursors and additives for geopolymer synthesis." Fire-resistant geopolymers, Springer briefs in materials, Second chapter, pp: 17-37.

Wild, S., Khatib, J.M., and ÓFarrell, M. (1997). "Sulphate resistance of mortar, containing ground brick clay calcined at different temperatures." Cement Concrete Research, Vol. 27, pp: 697-709. 